\title{
Update on mammalian sperm capacitation: how much does the horse differ from other species?
}

\author{
Bart Leemans ${ }^{1}$, Tom A E Stout ${ }^{2,3}$, Catharina De Schauwer ${ }^{1}$, Sonia Heras ${ }^{1}$, Hilde Nelis ${ }^{1}$, \\ Maarten Hoogewijs ${ }^{1}$, Ann Van Soom ${ }^{1}$ and Bart M Gadella ${ }^{3,4}$ \\ ${ }^{1}$ Department of Reproduction, Obstetrics and Herd Health, Faculty of Veterinary Medicine, Ghent University, \\ Ghent, Belgium, ${ }^{2}$ Department of Equine Sciences, Faculty of Veterinary Medicine, Utrecht University, Utrecht, \\ The Netherlands, ${ }^{3}$ Department of Farm Animal Health, Faculty of Veterinary Medicine, Utrecht University, \\ Utrecht, The Netherlands and ${ }^{4}$ Department of Biochemistry and Cell Biology, Faculty of Veterinary Medicine, \\ Utrecht University, Utrecht, The Netherlands
}

Correspondence should be addressed to B Leemans; Email: baleeman.leemans@ugent.be

\begin{abstract}
In contrast to various other mammalian species, conventional in vitro fertilization (IVF) with horse gametes is not reliably successful. In particular, stallion spermatozoa fails to penetrate the zona pellucida, most likely due to incomplete activation of stallion spermatozoa (capacitation) under in vitro conditions. In other mammalian species, specific capacitation triggers have been described; unfortunately, none of these is able to induce full capacitation in stallion spermatozoa. Nevertheless, knowledge of capacitation pathways and their molecular triggers might improve our understanding of capacitation-related events observed in stallion sperm. When sperm cells are exposed to appropriate capacitation triggers, several molecular and biochemical changes should be induced in the sperm plasma membrane and cytoplasm. At the level of the sperm plasma membrane, (1) an increase in membrane fluidity, (2) cholesterol depletion and (3) lipid raft aggregation should occur consecutively; the cytoplasmic changes consist of protein tyrosine phosphorylation and elevated $\mathrm{pH}, \mathrm{cAMP}$ and $\mathrm{Ca}^{2+}$ concentrations. These capacitation-related events enable the switch from progressive to hyperactivated motility of the sperm cells, and the induction of the acrosome reaction. These final capacitation triggers are indispensable for sperm cells to migrate through the viscous oviductal environment, penetrate the cumulus cells and zona pellucida and, finally, fuse with the oolemma. This review will focus on molecular aspects of sperm capacitation and known triggers in various mammalian species. Similarities and differences with the horse will be highlighted to improve our understanding of equine sperm capacitation/fertilizing events.

Reproduction (2019) 157 R181-R197
\end{abstract}

\section{Introduction}

Conventional in vitro fertilization (IVF), that is co-incubation of mature oocytes with capacitated sperm in a petri dish, is a standard procedure for producing embryos in vitro in a range of species, including man (Steptoe \& Edwards 1978), the cow (Perry 2013), the pig and various laboratory animals (Galli et al. 2003, Betteridge 2006). By contrast, conventional IVF has to date been very poorly successful in the horse. Equine IVF is hampered by the inability of stallion spermatozoa to penetrate the zona pellucida in vitro (Tremoleda et al. 2003). In theory, this failure could be attributed to deficiencies in either in vitro prepared sperm and/ or in vitro matured oocytes. Given that in vitro matured oocytes placed in the oviduct can be fertilized in vivo (Hinrichs et al. 2002), while in vivo matured oocytes harvested from pre-ovulatory follicles cannot be fertilized in vitro (Palmer et al. 1991), the inability of sperm cells to penetrate the zona pellucida ex vivo is most likely the result of deficient capacitation, that is activation of spermatozoa (Tremoleda et al. 2003). Although current equine IVF conditions do support the binding of stallion sperm to the oocyte's zona pellucida, this does not result in subsequent initiation of the acrosome reaction mandatory to penetrate the oocyte (Tremoleda et al. 2003). In contrast to sperm cells from other mammalian species, stallion sperm incubated under typical IVF conditions, that is in medium containing $\mathrm{HCO}_{3}{ }^{-}, \mathrm{Ca}^{2+}$ and albumin, also fail to display other capacitationrelated characteristics, such as hyperactivated motility, increased plasma membrane fluidity and protein tyrosine phosphorylation (Tremoleda et al. 2003) (Fig. 1).

Capacitation is the maturation process that sperm cells undergo after ejaculation, during their passage through the female genital tract (Suarez 2002). These biochemical changes enable the sperm to bind to and penetrate the zona pellucida and subsequently fuse with the oocyte (Fig. 1) (Yanagimachi 1994). The sperm 


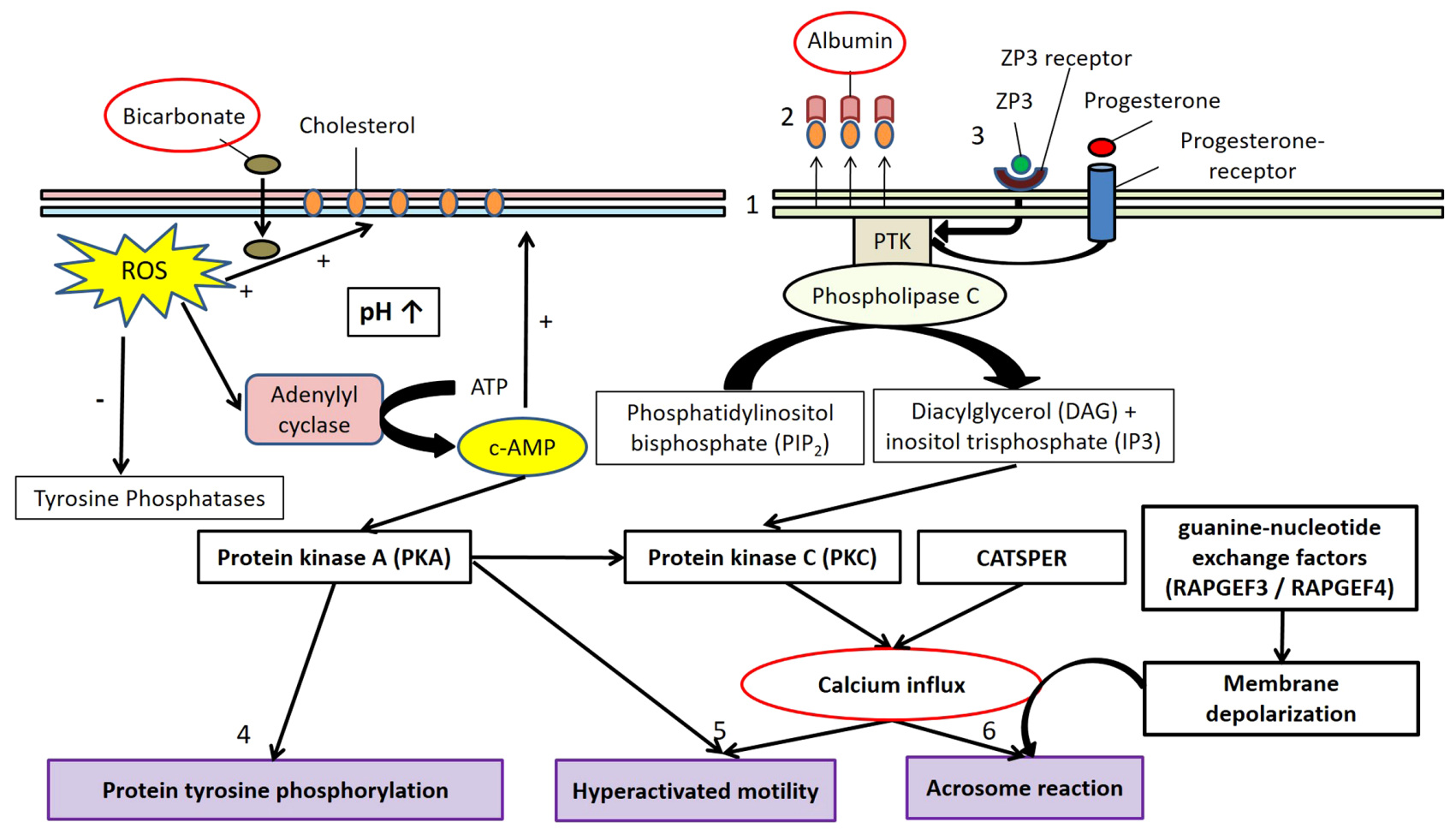

Figure 1 Pathways involved in sperm capacitation, with emphasis on the horse. When spermatozoa undergo capacitation, the following changes occur: (1) increase in membrane fluidity, (2) cholesterol depletion, (3) aggregation of lipid raft receptors, (4) protein tyrosine phosphorylation, (5) hyperactivated motility and (6) the acrosome reaction. PTK, protein tyrosine kinase; ROS, reactive oxygen species; ZP3, ZP protein 3; ZP3-receptor, ZP protein 3-receptor; +, activation; -, inhibition.

plasma membrane fuses with the outer acrosomal membrane, resulting in the exocytotic event known as the acrosome reaction that involves the release of lytic enzymes which locally dissolve the zona pellucida. The sperm cells also acquire hyperactivated motility in order to 'drill' through the zona pellucida (Yanagimachi 1994). Equids are one of the exceptions, in which capacitation does not appear to progress as described above. Using an oviduct epithelial explant model, we identified physiological triggering of three important capacitation parameters, namely increased intracellular pH (Leemans et al. 2014), protein tyrosine phosphorylation in the sperm tail (Leemans et al. 2014, $2015 b$ ) and hyperactivated motility (Leemans et al. 2015b). However, this approach was not sufficient to induce the acrosome reaction and fertilization during co-incubation with oocytes. Hence, our understanding of sperm activation in the oviduct, the ability of these spermatozoa to achieve fertilizing competence and, in particular, the intracellular pathways involved in this process needs to improve. This review focuses on what is currently known about capacitation pathways in sperm cells of non-equine species, the provision of fuel to support the highly energy-dependent capacitation events and how much these events differ to capacitationrelated events observed in stallion spermatozoa.

\section{Energy metabolism in stallion spermatozoa to support energy-demanding, fertility-related processes such as capacitation}

Sperm capacitation and other fertility-related pathways require large quantities of energy. To fuel these crucial capacitation events, individual sperm cells must generate relatively large amounts of ATP. In various mammalian species including man and the mouse, sperm motility and the maintenance of membrane integrity rely predominantly on ATP generated by non-aerobic glucose metabolism via glycolysis (Mukai \& Okuno 2004, Storey 2008, du Plessis et al. 2015), as demonstrated by the fact that mitochondrial oxidative chain uncouplers did not affect sperm motility or membrane integrity in sperm suspended in glucose-containing media. By contrast, the proportion of membrane intact and motile stallion sperm, and the velocity of that motion, in glucose-enriched media were all significantly reduced after exposure to mitochondrial uncouplers (Gibb et al. 2014, Davila et al. 2016). Inhibiting complex IV or ATP synthase, two proteins on the inner mitochondrial membrane critical to electron flow during oxidative phosphorylation, had similar effects on stallion sperm (Davila et al. 2016). Moreover, subsequent uncoupling of mitochondria or inhibition of mitochondrial respiration led to a massive 
drop in cytoplasmic ATP concentrations in stallion spermatozoa. Overall, this indicates that maintenance of stallion sperm membrane integrity and motility, two important requirements for fertility, are highly dependent on aerobic production of ATP (Gibb et al. 2014, Plaza Davila et al. 2015). As a consequence of the requirement for stallion sperm to generate mitochondrial ATP aerobically, increased cytoplasmic concentrations of reactive oxygen species (ROS), such as superoxide anions and their reduced form, hydrogen peroxide, are observed during stallion sperm incubation and activation. In turn, this cytoplasmic ROS accumulation leads to increased production of metabolic by-products, and the combination of accumulating ROS and cytotoxic lipid aldehydes (acrolein, 4-hydroxynonenal and malondialdehyde) ultimately leads to massive lipid peroxidation and DNA damage and thereby accelerated cell death (Gibb et al. 2016). To counteract the adverse effect of endogenous ROS production, and enable ROS homeostasis (Jones 2006) or defense against oxidative stress, stallion seminal plasma contains relatively high concentrations of antioxidants such as catalase (Ortega Ferrusola et al. 2009), superoxide dismutase (Ball et al. 2000, Ortega Ferrusola et al. 2009), glutathione (Hemachand \& Shaha 2003, Jones 2006) and ergothioneine (Mann 1975). Moreover, mitochondrial aldehyde dehydrogenase 2 has been identified in stallion sperm cells and proposed to serve as a detoxifier of aldehydes generated either endogenously or exogenously (Gibb et al. 2016). However, ROS defense mechanisms will eventually become exhausted and are not thus completely protective against sperm cell degeneration.

In this aspect, an interesting observation has been made with respect to stallion sperm oxidative stress and fertility. Spermatozoa from matings that did result in conception (and therefore considered 'more fertile') had lower percentages of membrane intact and higher percentages of cells displaying ROS-induced damage than spermatozoa from matings that did not result in conception (Gibb et al. 2014). It has been proposed that this can be explained by the fact that fertile stallions produce metabolically more active sperm cells that exhibit higher levels of oxidative phosphorylation. This will result in higher concentrations of ROS, leading to increased lipid peroxidation and, in turn, impaired sperm motility and membrane integrity in more fertile stallions. This has led to the suggestion that spermatozoa from highly fertile stallions 'live fast and die young'. It should also be borne in mind that a modest degree of cytoplasmic ROS production plays an important physiological role in sperm capacitation. These aspects are discussed below.

\section{How to trigger capacitation in vitro?}

In vivo, capacitation is initiated when a sperm cell is exposed to the environment within the female genital tract, that is the uterus and oviduct, close to the time of ovulation (reviewed by Leemans et al. (2016a)); capacitation events can be mimicked in vitro by incubating sperm cells in medium containing $\mathrm{HCO}_{3}{ }^{-}$, $\mathrm{Ca}^{2+}$ and albumin, after performing density gradient centrifugation (e.g. Percoll) to separate the sperm cells from the seminal plasma. $\mathrm{HCO}_{3}{ }^{-}, \mathrm{Ca}^{2+}$ and albumin are three capacitation factors known to induce the sperm changes required for the acquisition of fertilizing potential across many species (mice: Visconti et al. 1995a,b; hamster: Visconti et al. 1999b; man: Osheroff et al. 1999; pig: Flesch \& Gadella 2000). In addition, species-specific factors have been identified. In cattle, for example, heparin-like molecules such as glycosaminoglycans are an essential capacitation trigger (Parrish et al. 1988). Unfortunately, the species-specific capacitation triggers required to establish a repeatable, effective equine IVF system have yet to be identified. In various studies of stallion sperm capacitation, 'capacitating medium' has included the three general capacitation triggers $\left(\mathrm{HCO}_{3}^{-}, \mathrm{Ca}^{2+}\right.$ and albumin) even though it is known that full capacitation is not accomplished; non-capacitating medium, lacking these three triggers, is used as control medium (McPartlin et al. 2008, Leemans et al. 2016b). In Table 1, an overview of molecules frequently used as capacitation triggers in mammals, including the horse, is shown.

\section{Capacitation events}

Although capacitation was described for the first time in 1951 (Chang 1951, Austin 1952), the process is still not completely understood. It is known that capacitation involves a series of changes including (1) the removal of seminal plasma and surface-adhered decapacitation factors from the sperm plasma membrane, (2) reorganization of the sperm plasma membrane and (3) activation of intracellular pathways (Fig. 1).

After the removal of seminal plasma, a rapid increase in membrane fluidity (within $10 \mathrm{~min}$ ) is induced by an increasing intracellular $\mathrm{HCO}_{3}{ }^{-}$concentration and the activation of second messenger systems, including soluble adenylyl cyclase and a rise in intracellular $\mathrm{Ca}^{2+}$ (pig: Flesch \& Gadella 2000, Gadella et al. 2008; horse: Rathi et al. 2003). The activation of soluble adenylyl cyclase and the concomitant production of cAMP results in depletion of cholesterol from the sperm plasma membrane via a cholesterol acceptor such as albumin $(>1 \mathrm{~h})$, which is followed by a slower series of functional membrane changes in which lipid ordered microdomains aggregate at the apical ridge of the sperm head ( $>1 \mathrm{~h}$ ) (pig: van Gestel et al. 2005a). These microdomains contain functional zona pellucidabinding protein complexes (pig: van Gestel et al. 2007) and the soluble $\mathrm{N}$-ethylmaleimide-sensitive factor attachment protein receptor (SNARE) proteins, which play an important role in the induction of the acrosome 
R184 B Leemans and others

Table 1 Overview of capacitation triggers and their in vitro capacitation effect in different mammalian species.

\begin{tabular}{|c|c|c|c|}
\hline Capacitating trigger & Capacitation effect & Species & Reference \\
\hline \multirow[t]{5}{*}{$\mathrm{Ca}^{2+}$} & Membrane fluidity & Mouse & Visconti et al. $(1995 a, b)$ \\
\hline & Protein tyrosine phosphorylation & Man & Osheroff et al. (1999) \\
\hline & Hyperactivated motility & Pig & Flesch \& Gadella (2000) \\
\hline & Acrosome reaction & Cow & Byrd (1981), Breininger et al. (2010) \\
\hline & & Horse & McPartlin et al. (2008) \\
\hline \multirow[t]{6}{*}{$\mathrm{HCO}_{3}^{-}$} & Membrane fluidity & Mouse & Visconti et al. $(1995 a, b)$ \\
\hline & Protein tyrosine phosphorylation & Hamster & Visconti et al. (1999b) \\
\hline & Hyperactivated motility & Man & Osheroff et al. (1999) \\
\hline & Acrosome reaction & Pig & Flesch \& Gadella (2000) \\
\hline & & Cow & Breininger et al. (2010) \\
\hline & & Horse & Rathi et al. (2003), McPartlin et al. (2008) \\
\hline \multirow[t]{4}{*}{ Albumin } & Cholesterol depletion & Mouse & Visconti et al. $(1995 a, b)$ \\
\hline & & Pig & Flesch \& Gadella (2000) \\
\hline & & Cow & Byrd (1981) \\
\hline & & Horse & McPartlin et al. (2008) \\
\hline \multirow[t]{3}{*}{ Methyl $\beta$-cyclodextrin } & Cholesterol extraction & Mouse & Visconti et al. (1999a) \\
\hline & & Pig & van Gestel et al. (2005b) \\
\hline & & Horse & Bromfield et al. (2014) \\
\hline \multirow[t]{4}{*}{ Heparin } & Membrane fluidity & Cow & Parrish et al. (1988), Gualtieri et al. (2005), \\
\hline & Hyperactivated motility & & Breininger et al. (2010) \\
\hline & Protein tyrosine phosphorylation & & \\
\hline & Acrosome reaction & & \\
\hline \multirow[t]{2}{*}{ Progesterone } & Acrosome reaction & Horse & Cheng et al. $(1998 a, b)$ \\
\hline & Hyperactivated motility & Man & Lishko et al. (2011) \\
\hline \multirow[t]{6}{*}{$\mathrm{Ca}^{2+}$ ionophore $\mathrm{A} 23187$} & Acrosome reaction & Mouse & Tateno et al. (2013) \\
\hline & & Man & Bielfeld et al. (1994), Liu et al. (2011) \\
\hline & & Pig & \\
\hline & & Cow & Birck et al. (2009) \\
\hline & & Horse & Fraser et al. (1995) \\
\hline & Hyperactivated motility & Mice & Balao da Silva et al. (2013), Tateno et al. (2013) \\
\hline Lysophospha-tidylcholine & Acrosome reaction & Horse & Graham (1996) \\
\hline \multirow[t]{3}{*}{ C-AMP and caffeine } & Protein tyrosine phosphorylation & Cow & Breininger et al. (2010) \\
\hline & & Horse & Pommer et al. (2003) \\
\hline & Hyperactivated motility & Pig & Funahashi \& Nagai (2001) \\
\hline \multirow[t]{2}{*}{ ROS } & Protein tyrosine phosphorylation & Cow & Breininger et al. (2010) \\
\hline & & Horse & Baumber et al. (2003) \\
\hline \multirow[t]{2}{*}{ Alkaline medium $\mathrm{pH}$} & Protein tyrosine phosphorylation & Horse & Gonzalez-Fernandez et al. (2012) \\
\hline & Hyperactivated motility & Cow & Marquez \& Suarez (2007) \\
\hline \multirow[t]{2}{*}{ Procaine } & Hyperactivated motility & Guinea pig & Mujica et al. (1994) \\
\hline & & Horse & McPartlin et al. (2009), Leemans et al. (2015a) \\
\hline
\end{tabular}

reaction (pig: Tsai et al. 2010, 2012). Simultaneously, the production of cAMP enables the activation of protein kinase $\mathrm{A}$ which is required to phosphorylate the tyrosine residues on sperm proteins (Rathi et al. 2003, ljiri et al. 2012, Signorelli et al. 2012). In various species, this cAMP-dependent protein tyrosine phosphorylation, especially in the sperm tail, has been associated with the acquisition of hyperactivated sperm motility and is considered a marker for some essential elements of the capacitation process (mouse: Visconti et al. 1995a,b; pig: Flesch et al. 1999, Harayama et al. 2012).

\section{Plasma membrane changes}

Spermatozoa have a highly polarized morphology with a heterogenic surface differentiated into at least four surface membrane domains: the apical ridge and the pre-equatorial, equatorial and post-equatorial surface areas, respectively. Each of these regions plays a specific role in fertilization: (1) the apical ridge facilitates zona pellucida-binding (rabbit: O'Rand \& Fisher 1987), (2) the apical ridge, together with the pre-equatorial surface area, is involved in the acrosome reaction while (3) the equatorial surface area initiates binding to the oolemma and the subsequent fertilization fusion. These events occur in the region of the sperm head where the sperm plasma membrane, including the lipid rafts (microdomains), covers the acrosome and plays an essential role in the dynamics of sperm capacitation (Gadella et al. 2008).

\section{Cholesterol depletion}

A redistribution of phospholipids in the surface of the sperm head is an essential step in the capacitation process. $\mathrm{HCO}_{3}{ }^{-}$/soluble adenylyl cyclase/cAMP mediate 
an increase in membrane fluidity, detected as enhanced merocyanine 540 binding (Gadella \& Harrison 2000, 2002), that enables the redistribution of cholesterol from the equatorial area to the apical part of the sperm plasma membrane, while seminolipids move retrogradely (pig: Gadella et al. 1994, 1995). Both molecules are considered to be plasma membrane stabilizers, which prevent membrane fusion prior to capacitation. The $\mathrm{HCO}_{3}{ }^{-}$-mediated repacking of the sperm surface lipids is also essential in enabling the efflux of cholesterol which further increases plasma membrane fluidity by allowing the aggregation of lipid rafts, another essential step in the reorganization of the plasma membrane.

In vitro, the extraction of cholesterol from the sperm plasma membrane can be achieved by the oxidation of membrane sterols (Boerke et al. 2013), or active cholesterol transporters that deliver free cholesterol to the hydrophobic pocket of albumin (Flesch et al. 2001). Brouwers et al. (bull: 2011) showed that the production of ROS is an essential step in oxysterol formation. ROS production at low levels during sperm capacitation was first demonstrated in 1993, and indicates that sperm capacitation should be considered an oxidative process dependent on the active generation of ROS (man: de Lamirande \& Gagnon 1993). This process may also help to regulate protein tyrosine phosphorylation, another important capacitation marker, by increasing cAMP production (Aitken et al. 2004, Aitken 2011) and suppressing tyrosine phosphatase activity (Takakura et al. 1999). Since oxysterols are more hydrophilic than intact cholesterol, they can more easily move through the plasma membrane to bind to sterol acceptor molecules like albumin. Indeed, the presence of bovine serum albumin in capacitating medium is essential because of its unique ability to scavenge hydrophilic oxidation products and facilitate cholesterol extraction (Boerke et al. 2008). An alternative macromolecule not of animal origin (important in terms of risk of disease transmission) is methyl $\beta$-cyclodextrin. Whereas albumin extracts only $20 \%$ of the cholesterol from the non-raft sperm plasma membrane fraction, methyl $\beta$-cyclodextrin extracts $50 \%$ of the cholesterol from the entire sperm plasma membrane, including the lipid rafts (pig: van Gestel et al. 2005b). However, methyl $\beta$-cyclodextrin might have a deteriorative effect on sperm cells, even in low concentrations. A deteriorative effect of methyl $\beta$-cyclodextrin on mouse oocytes has also been reported (Buschiazzo et al. 2013). In stallion sperm, however, standard capacitating conditions, that is inclusion of $\mathrm{Ca}^{2+}, \mathrm{HCO}_{3}{ }^{-}$and bovine serum albumin (individual or in combination), does not facilitate cholesterol removal from the sperm plasma membrane. Indeed, while $\mathrm{HCO}_{3}^{-}$ induces an increase in ROS, this is abolished by the addition of $\mathrm{Ca}^{2+}$ or albumin (Macias Garcia et al. 2015). These observations suggest a species-specific difference in the regulation of plasma membrane changes during stallion sperm capacitation.

\section{Aggregation of lipid rafts}

As demonstrated in pig spermatozoa, increased membrane fluidity and cholesterol depletion are followed by a redistribution of the laterally segregated molecules, that is lipid ordered microdomains aggregate at the apical ridge area of the sperm head (Boerke et al. 2008). The proteins and lipids which make up these microdomains also show a capacitation-dependent change to include higher proportions of cholesterol, sphingomyelin, gangliosides and phospholipids with saturated long-chain acyl chains and lipid-modified proteins such as GPI-anchored proteins (Simons \& Toomre 2000, van Gestel et al. 2005a). Moreover, caveolin-1 and flotillin-1 are lipid raft-specific markers (van Gestel et al. 2005a) that accumulate in these microdomains along with functional zona pellucida-binding protein complexes. In man, angiotensin-converting enzyme and protein disulfide isomerase A6 were identified in the microdomains as proteins able to interact with heat shock protein $\mathrm{A} 2$, which plays a pivotal role in the remodeling of the sperm surface during capacitation and the recognition of human oocytes (Bromfield et al. 2016). In pigs, it has been shown that isoforms of AQN-3 (spermadhesin), P47 (porcine homologue of SED-1), fertilin $\beta$ and peroxiredoxin 5 are key proteins regulating the primary binding between capacitated spermatozoa and the zona pellucida (van Gestel et al. 2007). However, it is not known whether these proteins reside in microdomains.

\section{Hyperactivated motility}

\section{General sperm motility}

A specific cytoplasmic $\mathrm{pH}$ is crucial to allow sperm motility. For de-membranated sperm, maximal percentages of motile sperm were recorded between $\mathrm{pH}$ 7.0 and 8.1 for bull (Ho et al. 2002), pH 7.8 for human (Giroux-Widemann et al. 1991) and between pH 7.5 and 8.0 for ram (Ishijima \& Witman 1987) spermatozoa. For comparison, the maximum percentage of motile stallion spermatozoa was observed in medium at $\mathrm{pH}$ 7.0 (Loux et al. 2014). An appropriate cytoplasmic $\mathrm{pH}$ enhances symmetrical flagellar, and therefore, progressive sperm motility, which requires the activation of dynein ATPases on phosphorylated dynein molecules and their interaction with $\mathrm{Ca}^{2+}$ which, in turn, results in the sliding of the adjacent outer axonemal doublet microtubules (Shingyoji et al. 1977). When the doublets slide along one another, the sliding force is translated into a bend in the sperm tail (Tash 1989). The normal flagellar waveform requires an asynchronous phosphorylation and dephosphorylation of the dynein arms along the complete axonemal length (Wargo \& Smith 2003). In mammals, sperm motility is mostly initiated and maintained by ATP, $\mathrm{Ca}^{2+}$ and $\mathrm{HCO}_{3}{ }^{-}$-driven cAMP-dependent phosphorylation of flagellar proteins 
(Tash \& Means 1983, White \& Aitken 1989, Ho et al. 2002). Like $\mathrm{HCO}_{3}{ }^{-}, \mathrm{Ca}^{2+}$ also directly regulates soluble adenylyl cyclase, which results in cAMP generation and activation of protein kinase A (Fig. 1) (Liguori et al. 2004, Hessetal. 2005). An important downstream target of CAMP in the sperm flagellum is serine/threonine kinase protein kinase A (Visconti et al. 1997). The phosphorylation of serine/threonine activates protein kinase A which results in the downstream phosphorylation of tyrosine kinases whose targets are primarily located in the sperm tail (man: Leclerc et al. 1996; mouse: Si \& Olds-Clarke 2000). On the other hand, dynein dephosphorylation is evoked by the calmodulin-dependent protein serine/ threonine phosphatase, calcineurin, which is necessary to balance the cAMP-driven serine/threonine kinases in the sperm tail. The resulting net phosphorylation represents the sperm motility status well (Tash \& Bracho 1994). If serine/threonine phosphatase activity is dominant, spermatozoa are mainly immotile whereas serine/threonine kinase activity correlates with increased motility (man and Rhesus monkey: Smith et al. 1996; bull: Vijayaraghavan et al. 1996).

\section{Relationship between $\mathrm{Ca}^{2+}, \mathrm{pH}$ and hyperactivated sperm motility?}

Sperm cells must acquire hyperactivated motility to (1) detach from their oviduct epithelial cell binding and leave the oviductal reservoir (Suarez \& Pacey 2006), (2) migrate through the viscous lumen of the oviduct (Suarez \& Dai 1992) and (3) penetrate the cumulus matrix and zona pellucida of the mature oocyte in order to fuse with the oolemma (Stauss et al. 1995). In many species, hyperactivated motility is characterized by a highly asymmetrical and high-amplitude flagellar beating pattern that gives rise to a whip-like motion of the sperm tail which, in vitro, results in circular, figure of eight or zigzag swimming trajectories (Yanagimachi 1994, Ishijima et al. 2006). The onset and maintenance of hyperactivated motility is associated with an influx of $\mathrm{Ca}^{2+}$ into the cytosol of the sperm tail (Suarez et al. 1993, Suarez 2008). Ho et al. (2002) showed in de-membranated bull sperm that a symmetrical, progressive sperm movement was maintained when the intracellular $\mathrm{Ca}^{2+}$ concentration was $\sim 50 \mathrm{nM}$. When hyperactivated motility was initiated, the intracellular $\mathrm{Ca}^{2+}$ concentration increased to $400 \mathrm{nM}$. By contrast, Loux et al. (2014) reported that the degree of hyperactivated motility was inversely related to the cytoplasmic $\mathrm{Ca}^{2+}$ concentration in stallion spermatozoa. Using a similar de-membranated sperm model, they demonstrated that an increasing $\mathrm{Ca}^{2+}$ concentration did not induce hyperactivated motility in stallion spermatozoa at any $\mathrm{pH}$. Moreover, cytoplasmic alkalinization induced both a hyperactivated motility response and cytoplasmic $\mathrm{Ca}^{2+}$ rise in intact sperm cells (Loux et al. 2013). Loux et al. (2013) observed an intracellular $\mathrm{pH}$ increase from 7.1 to 7.3-7.4 in hyperactivating conditions. A pH effect on the motility of de-membranated stallion spermatozoa was not apparent. However, an extremely low $\mathrm{Ca}^{2+}$ concentration ( $27 \mathrm{pM}$ ) was sufficient to maintain motility in de-membranated stallion sperm at pH 7.4 (Loux et al. 2014). Moreover, procaine which is considered a potent inducer of hyperactivated motility in intact stallion spermatozoa, acts independently to extracellular $\mathrm{Ca}^{2+}$ influx (Loux et al. 2013). Overall, a species-specific relationship between $\mathrm{Ca}^{2+}$ sensitivity and hyperactivated motility is apparent in the horse.

In vitro, $\mathrm{Ca}^{2+}$ ionophores such as $\mathrm{A} 23187$ or ionomycin can induce and maintain hyperactivated motility in mouse spermatozoa for several hours (Suarez et al. 1987, Tateno et al. 2013). Besides the reliable induction of the acrosome reaction in stallion spermatozoa, $\mathrm{Ca}^{2+}$ ionophore A23187 exposure results in a complete loss of sperm motility and membrane integrity within $1 \mathrm{~h}$ (Christensen et al. 1996, Rathi et al. 2001). It is possible that these adverse effects of $\mathrm{Ca}^{2+}$ ionophore on sperm motility and membrane integrity are related to the fact that stallion sperm, in contrast to other mammals, are dependent on mitochondrial ATP (as discussed above). In this respect, excessive mitochondrial $\mathrm{Ca}^{2+}$ concentration can lead to mitochondrial failure and initiate cell death (Contreras et al. 2010). Moreover, $\mathrm{Ca}^{2+}$ ionophores uncouple oxidative phosphorylation by inhibiting mitochondrial ATPase activity (Humes \& Weinberg 1980, Krumschnabel et al. 1999). As mentioned above, other inhibitors that uncouple oxidative phosphorylation adversely affect stallion sperm motility and membrane integrity (Gibb et al. 2014, Davila et al. 2016). This is because production of mitochondrial ATP to support stallion sperm motility and membrane integrity is severely compromised soon after exposure. This is a cause for concern with respect to a capacitation induction protocol, because sperm viability and motility would need to be conserved over a period of hours during in vitro fertilization. Other pharmacological agents such as caffeine (Ho \& Suarez 2001b), thimerosal (Ho \& Suarez 2001b, Marquez \& Suarez 2004) and thapsigargin (Ho \& Suarez 2001b, Ho \& Suarez 2003) also trigger an intracellular $\mathrm{Ca}^{2+}$ rise and initiate asymmetrical flagellar beating in mouse spermatozoa. The effect of these molecules on the cytoplasmic $\mathrm{Ca}^{2+}$ concentration and hyperactivated motility have yet to be studied in the horse.

In mammals such as man, cattle and mice, CATSPER channels present on the principal piece of the sperm tail's need be activated to induce hyperactivated motility. There are four CATSPER genes coding for proteins that are structurally similar to subunits of conventional voltage-gated cation channels. When a mouse single CATSPER gene knock-out was created, males were infertile because the spermatozoa were not able to achieve hyperactivated motility (Carlson et al. 2005, Qi et al. 2007). The general trigger of these CATSPER 
channels is alkaline depolarization evoked by a change in the oviductal ionic environment, which results in an elevated $\mathrm{pH}$ of the oviduct fluid (Carlson et al. 2003, Navarro et al. 2008). Contact between spermatozoa and the alkaline oviductal environment increases the intracellular $\mathrm{pH}$ and activates the CATSPER channels. In stallion sperm, CATSPER1 mRNA has been identified, and CATSPER1 protein was localized to the principal piece of the sperm tail. However, analysis of the equine CATSPER1 protein revealed species-specific differences in the structure in the $\mathrm{pH}$ sensor region (Loux et al. 2013). This indicated that, despite the presence of a CATSPER channel in stallion sperm, the relationship between hyperactivated motility and $\mathrm{Ca}^{2+}$ influx is likely to be weak.

A clear increase in oviduct $\mathrm{pH}$ and, as a consequence, in sperm cytoplasmic pH likely to activate the CATSPER channels, was observed in Rhesus monkeys approaching ovulation (7.1-7.3 to 7.5-7.8) (Maas et al. 1977). In the mouse, a $\mathrm{Na}^{+}$-dependent $\mathrm{Cl}^{-} / \mathrm{HCO}_{3}{ }^{-}$exchange controls the intracellular $\mathrm{pH}$ of the sperm (Zeng et al. 1996), while in man, an outflow of $\mathrm{H}^{+}$is initiated by activating a voltage-gated proton channel (Lishko et al. 2010). To maximize the subsequent $\mathrm{Ca}^{2+}$ entry through the CATSPER channels, both a pH-sensitive efflux of $\mathrm{K}^{+}$by KSPER (Navarro et al. 2007) and an activation of $\mathrm{Cl}^{-}$channels by closing $\mathrm{Na}^{+}$channels might support capacitation-related sperm plasma membrane hyperpolarization (mouse: Hernandez-Gonzalez et al. 2007). Hyperpolarization also plays a central role in the acrosome reaction. In human spermatozoa, it has been demonstrated that CATSPER channels can be alternatively activated by progesterone and, to a lesser extent, prostaglandins (Lishko et al. 2011). Other $\mathrm{Ca}^{2+}$ metabolism-related pathways identified in the mammalian sperm tail, include the following: (1) a transient receptor potential $\mathrm{Ca}^{2+}$ channel, which may affect sperm motility and re-sequestration of $\mathrm{Ca}^{2+}$ into sperm stores (Castellano et al. 2003), (2) cyclicnucleotide-gated $\mathrm{Ca}^{2+}$ channels (Wiesner et al. 1998) and (3) voltage-gated $\mathrm{Ca}^{2+}$ channels (Benoff 1998, Darszon et al. 2006). However, the role of the various $\mathrm{Ca}^{2+}$ regulatory pathways in the physiological activation of hyperactivated motility is unclear.

Besides the extracellular $\mathrm{Ca}^{2+}$ influx through the CATSPER channels, there are also intracellular $\mathrm{Ca}^{2+}$ stores, in the so-called redundant nuclear envelope (RNE) located at the base of the sperm tail, which are able to provide $\mathrm{Ca}^{2+}$ to the sperm cytoplasm ( $\mathrm{Ho}$ \& Suarez 2001b, 2003). Inositol 1,4,5-triphosphate $\left(\mathrm{IP}_{3}\right)$ gated channels on the RNE membranes trigger $\mathrm{Ca}^{2+}$ release to the sperm cytoplasm whereas calreticulin, a $\mathrm{Ca}^{2+}$ binding protein, sequesters $\mathrm{Ca}^{2+}$ in the RNE (bull: Ho \& Suarez 2001b, 2003; man: Naaby-Hansen et al. 2001). In the mouse, it has been shown that ryanodine receptors on the RNE membrane also play a role in intracellular $\mathrm{Ca}^{2+}$ release (Trevino et al. 1998).
As such, both $\mathrm{Ca}^{2+}$ sources contribute to initiation and maintenance of high $\mathrm{Ca}^{2+}$ concentrations during sperm hyperactivation (Ho \& Suarez 2001b, 2003). More specifically, the $\mathrm{Ca}^{2+}$-induced $\mathrm{Ca}^{2+}$ release from the RNE amplifies the intracellular $\mathrm{Ca}^{2+}$ rise resulting from CATSPER activation (Costello et al. 2009, Olson et al. 2010). Furthermore, this activation of CATSPER and IP - $^{-}$ gated channels is clearly involved in induction of the acrosome reaction (Quill et al. 2003, Ren et al. 2001). So far, a role of intracellular $\mathrm{Ca}^{2+}$ stores in the induction of hyperactivated motility in stallion spermatozoa is purely theoretical.

\section{Hypermotility is induced by $\mathrm{HCO}_{3}{ }^{-}$and $C a^{2+}$-driven pathways}

So far, it has not been elucidated how sperm cells modify the beat of their tail, at the molecular level. It is known that the $\mathrm{Ca}^{2+}$ rise and the subsequent onset of hyperactivated motility changes the sliding of the microtubules (Lindemann \& Lesich 2010). Furthermore, it has been demonstrated in primates (Mahony \& Gwathmey 1999), pigs (Harayama et al. 2012) and rodents (Si \& Okuno 1999) that hyperactivated motility is associated with a highly increased cAMP-dependent tyrosine phosphorylation of the flagellar proteins. The generator of tyrosine phosphorylation events, protein kinase A, is connected to the fibrous sheath of the sperm tail by A-kinase-anchoring proteins, and it has been suggested that these proteins play an important role in hyperactivated sperm motility (Hamster: Si 1999). Moreover, A-kinase-anchoring proteins could attach protein kinase $\mathrm{A}$ to specific subcellular regions in close proximity to motility-related targets in the axoneme (Carrera et al. 1994, Mandal et al. 1999). A-kinaseanchoring protein 3 and A-kinase-anchoring protein 4 play a central role in activating tyrosine kinases to cause extensive tyrosine phosphorylation of sperm tail proteins (hamster: Si 1999; man: Ficarro et al. 2003). This altered tail protein tyrosine phosphorylation status is required for the acquisition of hyperactivated sperm motility (hamster: Si 1999; man: Leclerc et al. 1996). Changes in A-kinase-anchoring protein-mediated protein targeting might also play an essential role in this process.

Independent of protein kinase $\mathrm{A}, \mathrm{Ca}^{2+}$ is involved in pathways regulating sperm motility. Calmodulin, located in the principal piece of the sperm tail (Schlingmann et al. 2007), is a $\mathrm{Ca}^{2+}$-binding protein essential to the $\mathrm{Ca}^{2+}$-dependent modulation of mammalian sperm motility (Ho \& Suarez 2001a, Ignotz \& Suarez 2005). It has been suggested that this pathway progresses in parallel with cAMP/protein kinase A activity, although the two act independently (Litvin et al. 2003, Schlingmann et al. 2007). Binding of $\mathrm{Ca}^{2+}$ to calmodulin activates $\mathrm{Ca}^{2+} /$ calmodulin-dependent kinases (MarinBriggiler et al. 2005) which phosphorylate a specific axonemal protein, resulting in hyperactivated motility 
(Suarez 2008). Calmodulin kinases present in the flagellum of bull (Ignotz \& Suarez 2005) and human (Marin-Briggiler et al. 2005) sperm were associated with hyperactivated motility. On the other hand, phosphatase activities are also directly involved in axonemal function because they reverse the latter effect by regulating dynein ATPase activities (Tash et al. 1988, Carrera et al. 1996) (Fig. 2).

\section{Is hyperactivated motility linked to protein tyrosine phosphorylation during stallion sperm capacitation?}

As indicated above, in various mammalian species it has been shown that hyperactivated motility is associated with a marked increase in CAMP/protein kinase A and $\mathrm{Ca}^{2+} /$ calmodulin-dependent kinase activity that induces tyrosine phosphorylation of the flagellar proteins that, in turn, alter the sliding of the microtubules within the sperm axoneme (mouse: Visconti et al. 1995a,b; pig: Flesch et al. 1999, Harayama et al. 2012). Surprisingly, hyperactivated motility and protein tyrosine phosphorylation can also occur independently (mouse: Olds-Clarke 1989; cow: Marquez \& Suarez 2004). This latter observation certainly seems to be true for stallion sperm. For example, type $10 \mathrm{sAC}$ induced protein tyrosine phosphorylation in stallion sperm, without initiating hyperactivated motility (McPartlin et al. 2011). An increased PKA activity and protein tyrosine phosphorylation without hyperactivation was also observed after incubating stallion spermatozoa in vitro with membrane-soluble cAMP analogues or a phosphodiesterase inhibitor (caffeine) (Pommer et al. 2003). ROS (Baumber et al. 2003) and modifiedWhitten's capacitating medium with higher alkalinity
( $\mathrm{pH}=7.8-8.0)$ (Gonzalez-Fernandez et al. 2012, 2013) also induce protein tyrosine phosphorylation in the absence of, or only a mild, hyperactivated motility response. Similarly, binding of stallion sperm to late pre-ovulatory stage oviduct epithelium induces protein tyrosine phosphorylation without hyperactivated motility. This protein tyrosine phosphorylation was regulated primarily by a high $\mathrm{pH}$ within oviductal secretory cells (Leemans et al. 2014). When stallion sperm are incubated in capacitating conditions at $\mathrm{pH} 7.4$, a $\mathrm{Ca}^{2+}$-mediated inhibitory effect on protein tyrosine phosphorylation occurs due to the formation of a $\mathrm{Ca}^{2+} / \mathrm{calmodulin}$ complex that supports sperm phosphatase activity (Gonzalez-Fernandez et al. 2012). Under alkaline-capacitating conditions $(\mathrm{pH}=7.8-$ 8.0) however, $\mathrm{Ca}^{2+} /$ calmodulin-dependent kinases dominate and play a downstream role in protein kinase A-dependent protein tyrosine phosphorylation. As such, $\mathrm{Ca}^{2+}$-induced protein tyrosine kinases activate protein tyrosine phosphorylation in stallion spermatozoa downstream of protein kinase A (Gonzalez-Fernandez et al. 2013).

Interestingly, after cryopreservation a premature induction of protein tyrosine phosphorylation is observed, commonly referred to as 'cryocapacitation' (Bailey et al. 2000, Watson 2000). The increased osmolality associated with cryopreservation may induce a ROSdependent increase in protein tyrosine phosphorylation in stallion sperm (Aitken et al. 1983, Burnaugh et al. 2010). After cryopreservation, sperm cells display an increased intracellular $\mathrm{Ca}^{2+}$ concentration, increased ROS generation and a reduced antioxidant capacity. Recently, Ortega-Ferrusola et al. (2017) examined the effect of cryopreservation on both apoptosis and

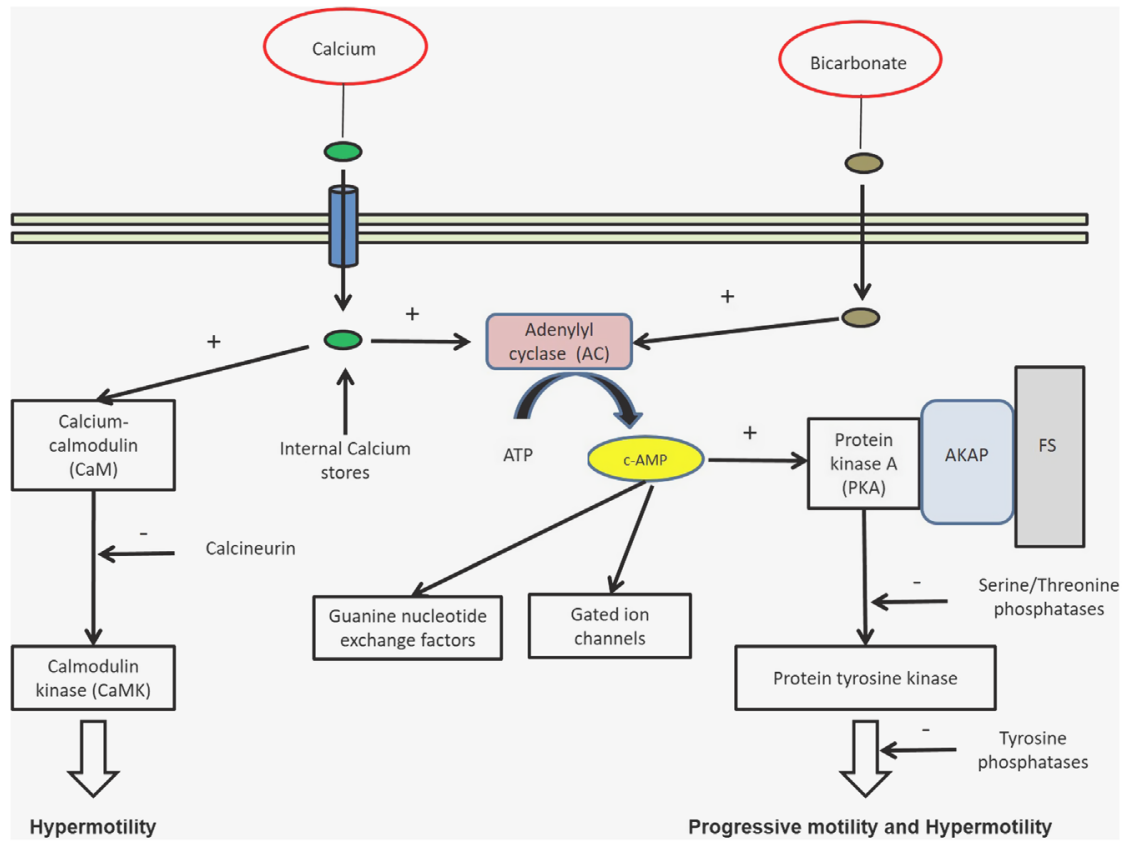

Figure 2 Schematic representation of signaling pathways involved in the regulation of mammalian sperm (hyper)motility. Progressive motility is regulated by low-level activity of the AC/cAMP/PKA pathway, while hyperactivated motility is induced when the latter pathway is activated to a much higher level, in combination with the activation of the calmodulin kinase (CaMK) pathway. Image modified from Turner (2006). 
premature capacitation-like changes simultaneously, to investigate the reduced longevity of frozen/thawed stallion sperm. In general, cryopreservation induced an increase in caspase 3 activity, translocation of phosphatidylserine from the inner to outer layer of the plasma membrane lipid bilayer, a reduction in mitochondrial membrane potential and an increased cytoplasmic $\mathrm{Na}^{+}$concentration, all of which indicate the occurrence of an apoptotic-like process in frozen/ thawed stallion sperm cells. Additionally, a small subpopulation of cryopreserved sperm showed capacitation-like characteristics after thawing, such as increased membrane fluidity and protein tyrosine phosphorylation. To avoid the negative effects of cooling and cryopreservation on stallion sperm, Gibb et al. (2015) recently described a promising approach to store stallion spermatozoa at room temperature. Taking into account that stallion spermatozoa rely heavily on mitochondrial ATP production which generates ROS (as discussed previously), combined supplementation of sperm storage medium with $10 \mathrm{mM}$ pyruvate and $50 \mathrm{mM}$ L-carnitine was found to counteract the adverse effects of ROS production during room temperature storage. Much improved preservation of sperm total and progressive motility after $72 \mathrm{~h}$ incubation and significantly higher acetyl-L-carnitine concentrations were observed using this antioxidant-enriched sperm storage medium.

In contrast to other mammalian species, no intracellular $\mathrm{Ca}^{2+}$ rise and activation of hyperactived motility is observed when stallion sperm are exposed to progesterone or prostaglandin $E_{1}$ (Loux et al. 2013). Other hyperactivation triggers for stallion sperm have been described, but do not support protein tyrosine phosphorylation in the sperm tail. For example, three parameters of progressive motility (straight line velocity, straightness and linearity) were decreased when stallion sperm was incubated in 10\% follicular fluid, indicating the acquisition of hyperactivated motility (LangeConsiglio \& Cremonesi 2012). Similarly, Leemans et al. (2015b) demonstrated the induction of hyperactivated motility when stallion spermatozoa were exposed to an alkaline follicular fluid fraction, while procaine also effectively induced hyperactivated motility in stallion spermatozoa; however, both did so in the absence of protein tyrosine phosphorylation (McPartlin et al. 2009, Leemans et al. 2015a).

\section{Acrosome reaction}

The $\mathrm{Ca}^{2+}$-dependent release of the acrosomal contents is an essential step in mammalian fertilization because it facilitates penetration through the acellular glycoprotein coat of the oocyte. After traversing the zona pellucida, the sperm cell will fuse with the oolemma of the mature oocyte (Yanagimachi 1994). In vivo, the acrosome reaction takes place in the female genital tract, at the site of fertilization. The acrosome reaction is a multipoint membrane fusion event between the sperm plasma membrane and the outer acrosomal membrane (Vigil 1989, Tsai et al. 2010), which results in the generation of mixed vesicles containing both plasma membrane and outer acrosomal membrane material. The remaining unfused acrosomal membranes, that is the equatorial area of the outer acrosome and the sperm plasma membrane connected to the inner acrosomal membrane covering the apical part of the nucleus, subsequently function as the sperm plasma membrane surface (Kim \& Gerton 2003, Vjugina \& Evans 2008). This re-designed outer sperm membrane contains a hairpin structure that is able to bind to the oolemma to enable gamete fusion and oocyte activation (Yanagimachi 1994). In boar sperm, it has been demonstrated that soluble $\mathrm{N}$-ethylmaleimide- SNARE protein interactions play a fundamental role in the fusion of the sperm plasma membrane and the outer acrosomal membrane, because a trans ternary-soluble $\mathrm{N}$-ethylmaleimide-sensitive factor attachment protein receptor protein complex is formed during capacitation. Key factors involved in this process are syntaxin $1 \mathrm{~B}$ and VAMP 3 from the plasma membrane, and SNAP 23 from the outer acrosomal membrane (Tsai et al. 2010). Additionally, the entry of $\mathrm{Ca}^{2+}$ (in vitro by use of $\mathrm{Ca}^{2+}$ ionophores; in vivo after $\mathrm{ZP}$ binding) is required to facilitate the conversion to cis-soluble $\mathrm{N}$-ethylmaleimide-SNARE complexes which will result in acrosomal exocytosis and penetration of the zona pellucida (Roggero et al. 2007).

In mice, one of the main molecules triggering the acrosome reaction in capacitated spermatozoa is zona pellucida glycoprotein 3 (ZP3) present on mature oocytes (Bleil \& Wassarman 1990, Yanagimachi 1994, Arnoult et al. 1999). More recently, it has been shown that only contact with the intercellular matrix of the cumulus cell complex was able to induce the acrosome reaction and allow mouse spermatozoa to pass through the zona pellucida (Inoue et al. 2011, Jin et al. 2011). In many other mammals, including the horse, it has been demonstrated that capacitated, acrosomeintact spermatozoa initiate zona pellucida binding (Yanagimachi 1994), although stallion spermatozoa showed a low incidence of acrosome reaction after $1 \mathrm{~h}$ of in vitro binding to the zona pellucida (Ellington et al. 1993, Cheng et al. 1996, Meyers et al. 1996). Progesterone, present in follicular fluid or cumulus cell secretions, is another factor that might be responsible for inducing the acrosome reaction in horse spermatozoa (Saaranen et al. 1993, Cheng et al. 1998a, LangeConsiglio \& Cremonesi 2012) (Fig. 1). Interestingly, the progesterone-induced acrosome reaction did not proceed in a protein kinase $\mathrm{A}$, but rather in a protein kinase $\mathrm{C}$ and protein tyrosine kinase-dependent manner (Rathi et al. 2003), which is very similar to the zona pellucida-mediated induction of the acrosome reaction. Indeed, Breitbart and Naor (1999) showed that zona pellucida protein 3 activates a sperm protein tyrosine 
kinase coupled to phospholipase C (PLC), which in turn stimulates protein kinase $\mathrm{C}$ by generating diacylglycerol (DAG) from phosphatidylinositol-biphosphate $\left(\mathrm{PIP}_{2}\right)$ (Fig. 1). How the generation of diacylglycerol eventually results in the onset of the acrosome reaction is not yet known. By contrast, when stallion spermatozoa are incubated in vitro in $\mathrm{HCO}_{3}{ }^{-}$-enriched conditions, the acrosome reaction is mainly supported by a protein kinase $\mathrm{A}$ instead of a protein tyrosine kinase and protein kinase C-dependent pathway (Rathi et al. 2003) (Fig. 1), indicating that progesterone and $\mathrm{HCO}_{3}{ }^{-}$induce the acrosome reaction in different ways. In vitro, the acrosome reaction can also be reliably induced by non-physiological triggers, such as $\mathrm{Ca}^{2+}$ ionophore in combination with $\mathrm{HCO}_{3}^{-}$(Rathi et al. 2001).

In mice and pigs, it has been demonstrated that several neurotransmitter receptor/ion channels are present in sperm cell membranes. At least two of these channels, the glycine receptor/ $\mathrm{Cl}^{-}$channel and a nicotinic acetylcholine receptor, are important for the ZP-initiated acrosome reaction, but not for the progesterone-initiated acrosome reaction (mouse: Meizel 2004; pig: Melendrez \& Meizel 1995). In general, the glycine receptor $/ \mathrm{Cl}^{-}$ channel is involved in inhibiting neurotransmission in the central nervous system, where glycine inhibits transmission by increasing $\mathrm{Cl}^{-}$influx through the glycine receptor $/ \mathrm{Cl}^{-}$channel to induce hyperpolarization (Betz \& Becker 1988). However, in some neurons, neutrophils, and glycerol kinase pseudogene 3 cells, glycine appears to cause depolarization by activating the glycine receptor/ $\mathrm{Cl}^{-}$channel (presumably stimulating $\mathrm{Cl}^{-}$efflux), resulting in an increased cytoplasmic $\mathrm{Ca}^{2+}$ concentration (Boehm et al. 1997, Tapia et al. 1997, Weaver et al. 1998). The latter has also been demonstrated in sperm cells which came into contact with zona pellucida proteins. The depolarizing effect was evident as $\mathrm{Ca}^{2+}$ influx through voltage-gated $\mathrm{Ca}^{2+}$ channels (Arnoult et al. 1996, Florman et al. 1998). This event initiated the onset of the acrosome reaction. In the horse, the potential role of a glycine receptor $/ \mathrm{Cl}^{-}$channel and/or a nicotinic acetylcholine receptor in the onset of the acrosome reaction has not been studied. McPartlin et al. (2011) showed that the cAMP-driven activation of guanine-nucleotide exchange factors (RAPGEF3/ RAPGEF4) induced a sperm membrane depolarization in capacitated stallion spermatozoa. Depolarizationdependent $\mathrm{Ca}^{2+}$ influx subsequently initiated acrosomal exocytosis. However, the activation of these factors did not play any role in the activation of protein kinase A or in protein tyrosine phosphorylation (Fig. 1).

\section{Equine IVF: an update}

Worldwide, only two IVF foals have been born, both more than 25 years ago in 1990-1991 (Palmer et al. 1991, Bézard et al. 1992). The success of IVF in these cases was attributed to in vitro co-incubation of equine oocytes with calcium ionophore-treated stallion spermatozoa. Unfortunately, neither this nor other equine IVF protocols have proven to be reproducible. Indeed, subsequent attempts have yielded extremely poor equine IVF results, with reported cleavage rates varying from 0 to 33\% (Zhang et al. 1990, Choi et al. 1994, Li et al. 1995, Dell'aquila et al. 1996, 1997a,b, Alm et al. 2001, Hinrichs et al. 2002, Tremoleda et al. 2003, Roasa et al. 2007, Mugnier et al. 2009a,b, LangeConsiglio \& Cremonesi 2012). A detailed overview of the published equine IVF studies was produced by Leemans et al. (2016a).

During the last decade, the utility of procaine in equine IVF media has been a topic of discussion. As mentioned previously, procaine is a potent inducer of hyperactivated motility in stallion spermatozoa (McPartlin et al. 2009, Leemans et al. 2015a). Indeed, procaine-induced hyperactivation of stallion spermatozoa can even be induced in non-capacitating medium in the absence of external $\mathrm{Ca}^{2+}$ (Loux et al. 2013), with CATSPER channels apparently not participating in procaineinduced hyperactivation (Loux et al. 2013). Initial reports further suggested that procaine promoted equine in vitro fertilization by inducing hyperactivated motility while other requisite sperm capacitation events, such

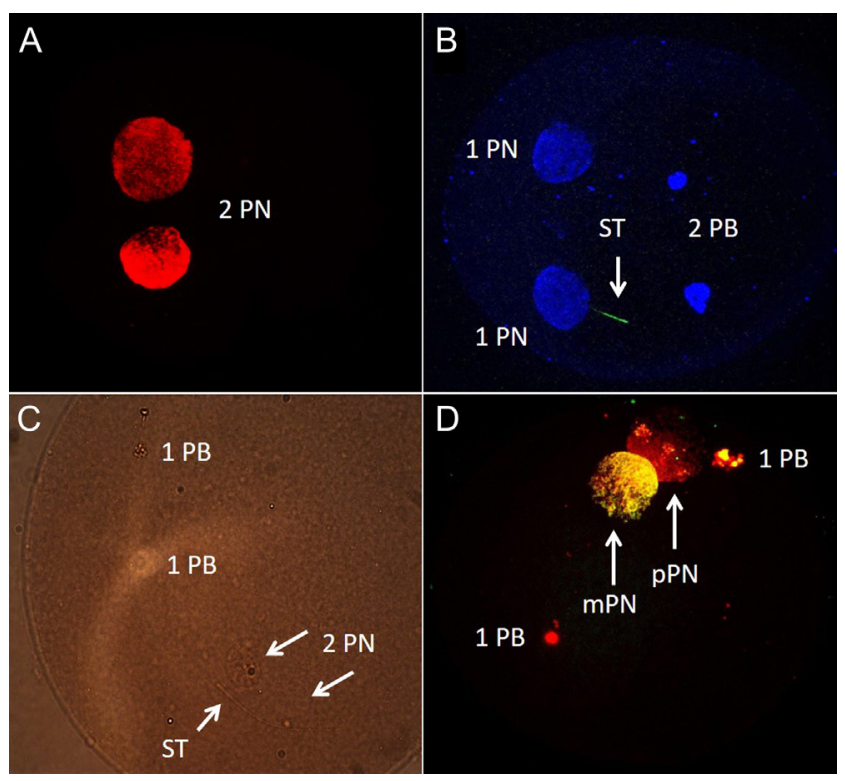

Figure 3 Methods to distinguish fertilization from parthenogenesis. (A) Previously the presence of 2 pronuclei (2 PN), evaluated using nuclear stains such as propidium iodide, was considered adequate to indicate fertilization of equine oocytes. However, this method cannot exclude parthenogenesis. Therefore, the additional presence of the sperm tail (ST) and the second extruded polar body (PB) shown by (B) MitoTracker Green FM pre-labeling combined with Hoechst post-fixation (Leemans et al. 2015a; published with permission from Oxford University Press (permission number 4450310125499)); (C) lacmoid post-fixation, should be demonstrated; or (D) paternal (pPN) and maternal (mPN) pronuclei in equine zygotes should be distinguished by different histone 3 methylation (H3K9me3) patterns. 
as protein tyrosine phosphorylation, were proposed to have been triggered by other medium constituents or a high pH (McPartlin et al. 2009, Ambruosi et al. 2013). Cleavage rates exceeding $60 \%$ of co-incubated oocytes were reported. However, none of these cleaved oocytes developed to the blastocyst stage. Leemans et al. (2015a) subsequently demonstrated that, although procaine did indeed trigger sperm hyperactivation, procaineinduced oocyte cytoplasmic cleavage also occurred in the absence of sperm. Moreover, gamete fusion induced oocyte activation, indicated by cytoplasmic $\mathrm{Ca}^{2+}$ oscillations, was not observed in the presence of procaine. It transpired that procaine acted further downstream in the oocyte-activation process, and only induced cytokinesis-like events via $\mathrm{pH}$-dependent depolymerization of F-actin, whereas nuclear activation was not triggered. Moreover, the procaine concentration used to induce sperm hyperactivated motility and oocyte cytokinesis was DNA toxic (Leemans et al. 2015a). Rather than true fertilization, procaine-induced DNA fragmentation with degeneration of the cleaving blastomeres occurring at the $8-16$ cell stage, that is stage of genome activation in horse embryos (Brinsko et al. 1995).

As a result of the initial misinterpretation, more stringent evaluation methods are clearly needed to confirm fertilization in horse oocytes. For various mammals, the presence of two pronuclei after 20-24 h gamete co-incubation, as visualized by nuclear chromatin stains such as Hoechst or propidium iodide, is considered valid proof of fertilization because of the low incidence of parthenogenesis (around $5 \%$ ) in current farm animal IVF systems (Beek et al. 2012, Heras et al. 2014, 2015). However, the presence of two pronuclei is not sufficient to distinguish normal fertilization from parthenogenesis in the horse. Using techniques such as pre-labeling sperm with MitoTracker Green FM/ Hoechst, and lacmoid post-fixation, Leemans et al. (2015a) were able to differentiate fertilization (two polar bodies within the perivitelline space, two pronuclei and a sperm tail within the ooplasm) from parthenogenesis (one polar body, one or two pronuclei and no sperm tail) (Fig. 3). Recently, a staining technique to differentiate the paternal from the maternal pronucleus in equine zygotes produced by intracytoplasmic sperm injection (ICSI) was established (Heras et al. 2015), based on different histone 3 methylation (H3K9me3) patterns. This staining technique could, however, not be used in the procaine experiments because the procaine-exposed oocytes did not form normal pronuclei but instead produced condensed DNA fragments (Fig. 3).

\section{Conclusion}

For more than 25 years, co-incubation of mature oocytes with capacitated sperm has been the standard method for producing in vitro embryos in several species including man, cattle, pigs and many laboratory animals. In the horse, however, conventional IVF still does not work. Inadequate capacitation of stallion spermatozoa under in vitro conditions is probably the major obstacle. It appears that several factors required to induce capacitation in other mammalian species are not involved in equine sperm capacitation. However, biological and chemical capacitation triggers have been identified to facilitate tail-associated protein tyrosine phosphorylation and hyperactivated motility in stallion sperm. However, since the acrosome reaction cannot be induced reliably using these factors, further research should focus on capacitation-related changes that prepare the sperm plasma and outer acrosomal membranes for fusion. It will be necessary to verify that 'improved' capacitation conditions support (1) cholesterol depletion from the sperm plasma membrane, (2) lateral redistribution of lipid rafts in the apical region and ultimately (3) the zona pellucida-induced acrosome reaction. It is likely that the induction of appropriate sperm plasma membrane changes will support the acrosome reaction. Only fully capacitated stallion spermatozoa will be able to penetrate the cumulus and zona pellucida barriers to accomplish fertilization.

\section{Declaration of interest}

The authors declare that there is no conflict of interest that could be perceived as prejudicing the impartially of this review.

\section{Funding}

This work was supported by the Research Foundation Flanders (FWO-Flanders; grant number $1210517 \mathrm{~N}$ ) and EU COST Action 16119 CellFit.

\section{References}

Aitken RJ 2011 The capacitation-apoptosis highway: oxysterols and mammalian sperm function. Biology of Reproduction 85 9-12. (https:// doi.org/10.1095/biolreprod.111.092528)

Aitken RJ, Wang YF, Liu J, Best F \& Richardson DW 1983 The influence of medium composition, osmolarity and albumin content on the acrosome reaction and fertilizing capacity of human spermatozoa: development of an improved zona-free hamster egg penetration test. International Journal of Andrology 6 180-193. (https://doi.org/10.1111/j.1365-2605.1983. tb00337.x)

Aitken RJ, Ryan AL, Baker MA \& McLaughlin EA 2004 Redox activity associated with the maturation and capacitation of mammalian spermatozoa. Free Radical Biology and Medicine 36 994-1010. (https:// doi.org/10.1016/j.freeradbiomed.2004.01.017)

Alm H, Torner H, Blottner S, Nurnberg G \& Kanitz W 2001 Effect of sperm cryopreservation and treatment with calcium ionophore or heparin on in vitro fertilization of horse oocytes. Theriogenology 56 817-829. (https:// doi.org/10.1016/S0093-691X(01)00610-0)

Ambruosi B, Accogli G, Douet C, Canepa S, Pascal G, Monget P, Moros Nicolas C, Holmskov U, Mollenhauer J, Robbe-Masselot C et al. 2013 Deleted in malignant brain tumor 1 is secreted in the oviduct and involved in the mechanism of fertilization in equine and porcine species. Reproduction 146 119-133. (https://doi.org/10.1530/REP-13-0007) 
Arnoult C, Cardullo RA, Lemos JR \& Florman HM 1996 Activation of mouse sperm T-type Ca2+ channels by adhesion to the egg zona pellucida. PNAS 93 13004-13009. (https://doi.org/10.1073/pnas.93.23.13004)

Arnoult C, Kazam IG, Visconti PE, Kopf GS, Villaz M \& Florman HM 1999 Control of the low voltage-activated calcium channel of mouse sperm by egg ZP3 and by membrane hyperpolarization during capacitation. PNAS 96 6757-6762. (https://doi.org/10.1073/pnas.96.12.6757)

Austin CR 1952 The capacitation of the mammalian sperm. Nature $\mathbf{1 7 0}$ 326. (https://doi.org/10.1038/170326a0)

Bailey JL, Bilodeau JF \& Cormier N 2000 Semen cryopreservation in domestic animals: a damaging and capacitating phenomenon. Journal of Andrology 21 1-7. (https://doi.org/10.1002/j.1939-4640.2000.tb03268.x)

Balao da Silva CM, Spinaci M, Bucci D, Giaretta E, Pena FJ, Mari G \& Galeati G 2013 Effect of sex sorting on stallion spermatozoa: heterologous oocyte binding, tyrosine phosphorylation and acrosome reaction assay. Animal Reproduction Science 141 68-74. (https://doi. org/10.1016/j.anireprosci.2013.07.008)

Ball BA, Gravance CG, Medina V, Baumber J \& Liu IK 2000 Catalase activity in equine semen. American Journal of Veterinary Research 61 1026-1030. (https://doi.org/10.2460/ajvr.2000.61.1026)

Baumber J, Sabeur K, Vo A \& Ball BA 2003 Reactive oxygen species promote tyrosine phosphorylation and capacitation in equine spermatozoa. Theriogenology 60 1239-1247. (https://doi.org/10.1016/ S0093-691X(03)00144-4)

Beek J, Nauwynck H, Maes D \& Van Soom A 2012 Inhibitors of zincdependent metalloproteases hinder sperm passage through the cumulus oophorus during porcine fertilization in vitro. Reproduction 144 687-697. (https://doi.org/10.1530/REP-12-0311)

Benoff S 1998 Voltage dependent calcium channels in mammalian spermatozoa. Frontiers in Bioscience 3 D1220-D1240. (https://doi. org/10.2741/A358)

Betteridge KJ 2006 Farm animal embryo technologies: achievements and perspectives. Theriogenology 65 905-913. (https://doi.org/10.1016/j. theriogenology.2005.09.005)

Betz H \& Becker CM 1988 The mammalian glycine receptor: biology and structure of a neuronal chloride channel protein. Neurochemistry International 13 137-146. (https://doi.org/10.1016/0197-0186(88)90048-4)

Bézard J, Magistrini M, Battut I, Duchamp G \& Palmer E 1992 In vitro fertilization in the mare. Recueil De Medecine Veterinaire 168 993-1003.

Bielfeld P, Anderson RA, Mack SR, De Jonge CJ \& Zaneveld LJ 1994 Are capacitation or calcium ion influx required for the human sperm acrosome reaction? Fertility and Sterility 62 1255-1261. (https://doi. org/10.1016/S0015-0282(16)57195-7)

Birck A, Labouriau R \& Christensen P 2009 Dynamics of the induced acrosome reaction in boar sperm evaluated by flow cytometry. Animal Reproduction Science $\mathbf{1 1 5} 124-136 . \quad$ (https://doi.org/10.1016/j. anireprosci.2008.10.017)

Bleil JD \& Wassarman PM 1990 Identification of a ZP3-binding protein on acrosome-intact mouse sperm by photoaffinity crosslinking. PNAS $\mathbf{8 7}$ 5563-5567. (https://doi.org/10.1073/pnas.87.14.5563)

Boehm S, Harvey RJ, von Holst A, Rohrer H \& Betz H 1997 Glycine receptors in cultured chick sympathetic neurons are excitatory and trigger neurotransmitter release. Journal of Physiology 504 683-694. (https://doi.org/10.1111/j.1469-7793.1997.683bd.x)

Boerke A, Tsai PS, Garcia-Gil N, Brewis IA \& Gadella BM 2008 Capacitation-dependent reorganization of microdomains in the apical sperm head plasma membrane: functional relationship with zona binding and the zona-induced acrosome reaction. Theriogenology $\mathbf{7 0}$ 1188-1196. (https://doi.org/10.1016/j.theriogenology.2008.06.021)

Boerke A, Brouwers JF, Olkkonen VM, van de Lest $\mathrm{CH}$, Sostaric E, Schoevers EJ, Helms JB \& Gadella BM 2013 Involvement of bicarbonateinduced radical signaling in oxysterol formation and sterol depletion of capacitating mammalian sperm during in vitro fertilization. Biology of Reproduction 88 21. (https://doi.org/10.1095/biolreprod.112.101253)

Breininger E, Cetica PD \& Beconi MT 2010 Capacitation inducers act through diverse intracellular mechanisms in cryopreserved bovine sperm. Theriogenology 74 1036-1049. (https://doi.org/10.1016/j. theriogenology.2010.04.034)

Breitbart H \& Naor Z 1999 Protein kinases in mammalian sperm capacitation and the acrosome reaction. Reviews of Reproduction 4 151-159. (https://doi.org/10.1530/ror.0.0040151)
Brinsko SP, Ball BA, Ignotz GG, Thomas PG, Currie WB \& Ellington JE 1995 Initiation of transcription and nucleologenesis in equine embryos. Molecular Reproduction and Development 42 298-302. (https://doi. org/10.1002/mrd.1080420306)

Bromfield EG, Aitken RJ, Gibb Z, Lambourne SR \& Nixon B 2014 Capacitation in the presence of methyl-beta-cyclodextrin results in enhanced zona pellucida-binding ability of stallion spermatozoa. Reproduction 147 153-166. (https://doi.org/10.1530/REP-13-0393)

Bromfield EG, McLaughlin EA, Aitken RJ \& Nixon B 2016 Heat shock protein member A2 forms a stable complex with angiotensin converting enzyme and protein disulfide isomerase A6 in human spermatozoa. Molecular Human Reproduction 22 93-109. (https://doi.org/10.1093/molehr/gav073)

Brouwers JF, Boerke A, Silva PF, Garcia-Gil N, van Gestel RA, Helms JB, van de Lest $\mathbf{C H}$ \& Gadella BM 2011 Mass spectrometric detection of cholesterol oxidation in bovine sperm. Biology of Reproduction $\mathbf{8 5}$ 128-136. (https://doi.org/10.1095/biolreprod.111.091207)

Burnaugh L, Ball BA, Sabeur K, Thomas AD \& Meyers SA 2010 Osmotic stress stimulates generation of superoxide anion by spermatozoa in horses. Animal Reproduction Science 117 249-260. (https://doi. org/10.1016/j.anireprosci.2009.05.014)

Buschiazzo J, laly-Radio C, Auer J, Wolf JP, Serres C, Lefevre B \& Ziyyat A 2013 Cholesterol depletion disorganizes oocyte membrane rafts altering mouse fertilization. PLoS One 8 e62919. (https://doi.org/10.1371/ journal.pone.0062919)

Byrd W 1981 In vitro capacitation and the chemically induced acrosome reaction in bovine spermatozoa. Journal of Experimental Zoology 215 35-46. (https://doi.org/10.1002/jez.1402150105)

Carlson AE, Westenbroek RE, Quill T, Ren D, Clapham DE, Hille B, Garbers DL \& Babcock DF 2003 CatSper1 required for evoked $\mathrm{Ca} 2+$ entry and control of flagellar function in sperm. PNAS $\mathbf{1 0 0}$ 14864-14868. (https://doi.org/10.1073/pnas.2536658100)

Carlson AE, Quill TA, Westenbroek RE, Schuh SM, Hille B \& Babcock DF 2005 Identical phenotypes of CatSper1 and CatSper2 null sperm. Journal of Biological Chemistry $28032238-32244$. (https://doi.org/10.1074/jbc. M501430200)

Carrera A, Gerton GL \& Moss SB 1994 The major fibrous sheath polypeptide of mouse sperm: structural and functional similarities to the A-kinase anchoring proteins. Developmental Biology 165 272-284. (https://doi.org/10.1006/dbio.1994.1252)

Carrera A, Moos J, Ning XP, Gerton GL, Tesarik J, Kopf GS \& Moss SB 1996 Regulation of protein tyrosine phosphorylation in human sperm by a calcium/calmodulin-dependent mechanism: identification of $A$ kinase anchor proteins as major substrates for tyrosine phosphorylation. Developmental Biology $\mathbf{1 8 0} \quad 284-296 . \quad$ (https://doi.org/10.1006/ dbio.1996.0301)

Castellano LE, Trevino CL, Rodriguez D, Serrano CJ, Pacheco J, Tsutsumi V, Felix R \& Darszon A 2003 Transient receptor potential (TRPC) channels in human sperm: expression, cellular localization and involvement in the regulation of flagellar motility. FEBS Letters 541 69-74. (https://doi. org/10.1016/S0014-5793(03)00305-3)

Chang MC 1951 Fertilizing capacity of spermatozoa deposited into the fallopian tubes. Nature 168697-698. (https://doi.org/10.1038/168697b0)

Cheng FP, Fazeli A, Voorhout WF, Marks A, Bevers MM \& Colenbrander B 1996 Use of peanut agglutinin to assess the acrosomal status and the zona pellucida-induced acrosome reaction in stallion spermatozoa. Journal of Andrology 17 674-682.

Cheng FP, Fazeli AR, Voorhout WF, Tremoleda JL, Bevers MM \& Colenbrander B 1998a Progesterone in mare follicular fluid induces the acrosome reaction in stallion spermatozoa and enhances in vitro binding to the zona pellucida. International Journal of Andrology 21 57-66. (https://doi.org/10.1046/j.1365-2605.1998.00096.x)

Cheng FP, Gadella BM, Voorhout WF, Fazeli A, Bevers MM \& Colenbrander B $1998 b$ Progesterone-induced acrosome reaction in stallion spermatozoa is mediated by a plasma membrane progesterone receptor. Biology of Reproduction 59 733-742. (https://doi.org/10.1095/ biolreprod59.4.733)

Choi YH, Okada Y, Hochi S, Braun J, Sato K \& Oguiri N 1994 Invitro fertilization rate of horse oocytes with partially removed zonae. Theriogenology 42 795-802. (https://doi.org/10.1016/0093691X(94)90448-R)

Christensen P, Whitfield CH \& Parkinson TJ 1996 In vitro induction of acrosome reactions in stallion spermatozoa by heparin and A23187. 
Theriogenology $45 \quad 1201-1210 . \quad$ (https://doi.org/10.1016/0093691X(96)00075-1)

Contreras L, Drago I, Zampese E \& Pozzan T 2010 Mitochondria: the calcium connection. Biochimica and Biophysica Acta 1797 607-618. (https://doi.org/10.1016/j.bbabio.2010.05.005)

Costello S, Michelangeli F, Nash K, Lefievre L, Morris J, MachadoOliveira G, Barratt C, Kirkman-Brown J \& Publicover S 2009 Ca2+stores in sperm: their identities and functions. Reproduction $\mathbf{1 3 8}$ 425-437. (https://doi.org/10.1530/REP-09-0134)

Darszon A, Lopez-Martinez P, Acevedo JJ, Hernandez-Cruz A \& Trevino CL 2006 T-type Ca2+ channels in sperm function. Cell Calcium 40 241-252. (https://doi.org/10.1016/j.ceca.2006.04.028)

Davila MP, Muñoz PM, Bolaños JM, Stout TA, Gadella BM, Tapia JA, da Silva CB, Ferrusola CO \& Peña FJ 2016 Mitochondrial ATP is required for the maintenance of membrane integrity in stallion spermatozoa, whereas motility requires both glycolysis and oxidative phosphorylation. Reproduction 152 683-694. (https://doi.org/10.1530/REP-16-0409)

de Lamirande E \& Gagnon C 1993 A positive role for the superoxide anion in triggering hyperactivation and capacitation of human spermatozoa. International Journal of Andrology 16 21-25. (https://doi. org/10.1111/j.1365-2605.1993.tb01148.x)

Dell'aquila ME, Fusco S, Lacalandra GM \& Maritato F 1996 In vitro maturation and fertilization of equine oocytes recovered during the breeding season. Theriogenology 45 547-560. (https://doi. org/10.1016/0093-691X(95)00402-T)

Dell'Aquila ME, Cho YS, Minoia P, Traina V, Fusco S, Lacalandra GM \& Maritato F 1997a Intracytoplasmic sperm injection (ICSI) versus conventional IVF on abottoir-derived and in vitro-matured equine oocytes. Theriogenology 47 1139-1156. (https://doi.org/10.1016/ S0093-691X(97)00095-2)

Dell'Aquila ME, Cho YS, Minoia P, Traina V, Lacalandra GM \& Maritato F $1997 b$ Effects of follicular fluid supplementation of in-vitro maturation medium on the fertilization and development of equine oocytes after invitro fertilization or intracytoplasmic sperm injection. Human Reproduction 12 2766-2772. (https://doi.org/10.1093/humrep/12.12.2766)

du Plessis SS, Agarwal A, Mohanty G \& van der Linde M 2015 Oxidative phosphorylation versus glycolysis: what fuel do spermatozoa use? Asian Journal of Andrology 17 230-235. (https://doi.org/10.4103/1008682X.135123)

Ellington JE, Ball BA \& Yang X 1993 Binding of stallion spermatozoa to the equine zona pellucida after coculture with oviductal epithelial cells. Journal of Reproduction and Fertility 98 203-208. (https://doi. org/10.1530/jrf.0.0980203)

Ficarro S, Chertihin O, Westbrook VA, White F, Jayes F, Kalab P, Marto JA, Shabanowitz J, Herr JC, Hunt DF et al. 2003 Phosphoproteome analysis of capacitated human sperm. Evidence of tyrosine phosphorylation of a kinase-anchoring protein 3 and valosin-containing protein/p97 during capacitation. Journal of Biological Chemistry 278 11579-11589. (https:// doi.org/10.1074/jbc.M202325200)

Flesch FM \& Gadella BM 2000 Dynamics of the mammalian sperm plasma membrane in the process of fertilization. Biochimica and Biophysica Acta 1469 197-235. (https://doi.org/10.1016/S0304-4157(00)00018-6)

Flesch FM, Colenbrander B, van Golde LM \& Gadella BM 1999 Capacitation induces tyrosine phosphorylation of proteins in the boar sperm plasma membrane. Biochemical and Biophysical Research Communications 262 787-792. (https://doi.org/10.1006/bbrc.1999.1300)

Flesch FM, Brouwers JF, Nievelstein PF, Verkleij AJ, van Golde LM, Colenbrander B \& Gadella BM 2001 Bicarbonate stimulated phospholipid scrambling induces cholesterol redistribution and enables cholesterol depletion in the sperm plasma membrane. Journal of Cell Science 114 3543-3555.

Florman HM, Arnoult C, Kazam IG, Li C \& O'Toole CM 1998 A perspective on the control of mammalian fertilization by egg-activated ion channels in sperm: a tale of two channels. Biology of Reproduction 59 12-16. (https://doi.org/10.1095/biolreprod59.1.12)

Fraser LR, Abeydeera LR \& Niwa K $1995 \mathrm{Ca}(2+)$-regulating mechanisms that modulate bull sperm capacitation and acrosomal exocytosis as determined by chlortetracycline analysis. Molecular Reproduction and Development 40 233-241. (https://doi.org/10.1002/mrd.1080400213)

Funahashi H \& Nagai T 2001 Regulation of in vitro penetration of frozen-thawed boar spermatozoa by caffeine and adenosine. Molecular Reproduction and Development $\mathbf{5 8} \quad 424-431$.
(https://doi.org/10.1002/1098-2795(20010401)58:4<424::AIDMRD10>3.0.CO;2-1)

Gadella BM \& Harrison RA 2000 The capacitating agent bicarbonate induces protein kinase A-dependent changes in phospholipid transbilayer behavior in the sperm plasma membrane. Development 127 2407-2420.

Gadella BM \& Harrison RA 2002 Capacitation induces cyclic adenosine 3',5'-monophosphate-dependent, but apoptosis-unrelated, exposure of aminophospholipids at the apical head plasma membrane of boar sperm cells. Biology of Reproduction 67 340-350. (https://doi.org/10.1095/ biolreprod67.1.340)

Gadella BM, Gadella TW Jr, Colenbrander B, van Golde LM \& LopesCardozo M 1994 Visualization and quantification of glycolipid polarity dynamics in the plasma membrane of the mammalian spermatozoon. Journal of Cell Science 107 (Pt 8) 2151-2163.

Gadella BM, Lopes-Cardozo M, van Golde LM, Colenbrander B \& Gadella TW, Jr 1995 Glycolipid migration from the apical to the equatorial subdomains of the sperm head plasma membrane precedes the acrosome reaction. Evidence for a primary capacitation event in boar spermatozoa. Journal of Cell Science 108 (Pt 3) 935-946.

Gadella BM, Tsai PS, Boerke A \& Brewis IA 2008 Sperm head membrane reorganisation during capacitation. International Journal of Developmental Biology 52 473-480. (https://doi.org/10.1387/ ijdb.082583bg)

Galli C, Duchi R, Crotti G, Turini P, Ponderato N, Colleoni S, Lagutina I \& Lazzari G 2003 Bovine embryo technologies. Theriogenology 59 599-616. (https://doi.org/10.1016/S0093-691X(02)01243-8)

Gibb Z, Lambourne SR \& Aitken RJ 2014 The paradoxical relationship between stallion fertility and oxidative stress. Biology of Reproduction 91 77. (https://doi.org/10.1095/biolreprod.114.118539)

Gibb Z, Lambourne SR, Quadrelli J, Smith ND \& Aitken RJ 2015 L-carnitine and pyruvate are prosurvival factors during the storage of stallion spermatozoa at room temperature. Biology of Reproduction 93 104. (https://doi.org/10.1095/biolreprod.115.131326)

Gibb Z, Lambourne SR, Curry BJ, Hall SE \& Aitken RJ 2016 Aldehyde dehydrogenase plays a pivotal role in the maintenance of stallion sperm motility. Biology of Reproduction 94 133. (https://doi.org/10.1095/ biolreprod.116.140509)

Giroux-Widemann V, Jouannet P, Pignot-Paintrand I \& Feneux D 1991 Effects of $\mathrm{pH}$ on the reactivation of human spermatozoa demembranated with Triton X-100. Molecular Reproduction and Development 29 157-162. (https://doi.org/10.1002/mrd.1080290211)

Gonzalez-Fernandez L, Macias-Garcia B, Velez IC, Varner DD \& Hinrichs K 2012 Calcium-calmodulin and pH regulate protein tyrosine phosphorylation in stallion sperm. Reproduction 144 411-422. (https:// doi.org/10.1530/REP-12-0067)

Gonzalez-Fernandez L, Macias-Garcia B, Loux SC, Varner DD \& Hinrichs K 2013 Focal adhesion kinases and calcium/calmodulindependent protein kinases regulate protein tyrosine phosphorylation in stallion sperm. Biology of Reproduction 88 138. (https://doi.org/10.1095/ biolreprod.112.107078)

Graham JK 1996 Methods for induction of capacitation and the acrosome reaction of stallion spermatozoa. Veterinary Clinics of North America. Equine Practice 12 111-117. (https://doi.org/10.1016/S07490739(17)30298-5)

Gualtieri R, Boni R, Tosti E, Zagami M \& Talevi R 2005 Intracellular calcium and protein tyrosine phosphorylation during the release of bovine sperm adhering to the fallopian tube epithelium in vitro. Reproduction 129 51-60. (https://doi.org/10.1530/rep.1.00374)

Harayama H, Noda T, Ishikawa S \& Shidara O 2012 Relationship between cyclic AMP-dependent protein tyrosine phosphorylation and extracellular calcium during hyperactivation of boar spermatozoa. Molecular Reproduction and Development 79 727-739. (https://doi. org/10.1002/mrd.22106)

Hemachand T \& Shaha C 2003 Functional role of sperm surface glutathione S-transferases and extracellular glutathione in the haploid spermatozoa under oxidative stress. FEBS Letters 538 14-18. (https://doi.org/10.1016/ S0014-5793(03)00103-0)

Heras S, Forier K, Rombouts K, Braeckmans K \& Van Soom A 2014 DNA counterstaining for methylation and hydroxymethylation immunostaining in bovine zygotes. Analytical Biochemistry 454 14-16. (https://doi.org/10.1016/j.ab.2014.03.002) 
Heras S, Smits K, Leemans B \& Van Soom A 2015 Asymmetric histone 3 methylation pattern between paternal and maternal pronuclei in equine zygotes. Analytical Biochemistry 471 67-69. (https://doi.org/10.1016/j. ab.2014.11.005)

Hernandez-Gonzalez EO, Trevino CL, Castellano LE, de la Vega-Beltran JL, Ocampo AY, Wertheimer E, Visconti PE \& Darszon A 2007 Involvement of cystic fibrosis transmembrane conductance regulator in mouse sperm capacitation. Journal of Biological Chemistry 282 24397-24406. (https:// doi.org/10.1074/jbc.M701603200)

Hess KC, Jones BH, Marquez B, Chen Y, Ord TS, Kamenetsky M, Miyamoto C, Zippin JH, Kopf GS, Suarez SS et al. 2005 The "soluble" adenylyl cyclase in sperm mediates multiple signaling events required for fertilization. Developmental Cell 9 249-259. (https://doi.org/10.1016/j. devcel.2005.06.007)

Hinrichs K, Love CC, Brinsko SP, Choi YH \& Varner DD 2002 In vitro fertilization of in vitro-matured equine oocytes: effect of maturation medium, duration of maturation, and sperm calcium ionophore treatment, and comparison with rates of fertilization in vivo after oviductal transfer. Biology of Reproduction 67 256-262. (https://doi. org/10.1095/biolreprod67.1.256)

Ho HC \& Suarez SS 2001a Hyperactivation of mammalian spermatozoa: function and regulation. Reproduction 122 519-526. (https://doi. org/10.1530/rep.0.1220519)

Ho HC \& Suarez SS $2001 b$ An inositol 1,4,5-trisphosphate receptor-gated intracellular $\mathrm{Ca}(2+)$ store is involved in regulating sperm hyperactivated motility. Biology of Reproduction 65 1606-1615. (https://doi. org/10.1095/biolreprod65.5.1606)

Ho HC \& Suarez SS 2003 Characterization of the intracellular calcium store at the base of the sperm flagellum that regulates hyperactivated motility. Biology of Reproduction 68 1590-1596. (https://doi.org/10.1095/ biolreprod.102.011320)

Ho HC, Granish KA \& Suarez SS 2002 Hyperactivated motility of bull sperm is triggered at the axoneme by $\mathrm{Ca} 2+$ and not cAMP. Developmental Biology 250 208-217. (https://doi.org/10.1006/dbio.2002.0797)

Humes HD \& Weinberg JM 1980 lonophore A23187 induced reductions in toad urinary bladder epithelial cell oxidative phosphorylation and viability: implications for A23187 related declines in epithelial active transport. Pflugers Archiv 388 217-230. (https://doi.org/10.1007/ BF00658484)

Ignotz GG \& Suarez SS 2005 Calcium/calmodulin and calmodulin kinase II stimulate hyperactivation in demembranated bovine sperm. Biology of Reproduction 73 519-526. (https://doi.org/10.1095/biolreprod.105.040733)

Ijiri TW, Mahbub Hasan AK \& Sato K 2012 Protein-tyrosine kinase signaling in the biological functions associated with sperm. Journal of Signal Transduction 2012 181560. (https://doi.org/10.1155/2012/181560)

Inoue N, Satouh Y, Ikawa M, Okabe M \& Yanagimachi R 2011 Acrosomereacted mouse spermatozoa recovered from the perivitelline space can fertilize other eggs. PNAS 108 20008-20011. (https://doi.org/10.1073/ pnas.1116965108)

Ishijima S \& Witman GB 1987 Flagellar movement of intact and demembranated, reactivated ram spermatozoa. Cell Motility and the Cytoskeleton 8 375-391. (https://doi.org/10.1002/cm.970080410)

Ishijima S, Mohri H, Overstreet JW \& Yudin Al 2006 Hyperactivation of monkey spermatozoa is triggered by $\mathrm{Ca} 2+$ and completed by cAMP. Molecular Reproduction and Development 73 1129-1139. (https://doi. org/10.1002/mrd.20420)

Jin M, Fujiwara E, Kakiuchi Y, Okabe M, Satouh Y, Baba SA, Chiba K \& Hirohashi N 2011 Most fertilizing mouse spermatozoa begin their acrosome reaction before contact with the zona pellucida during in vitro fertilization. PNAS $\mathbf{1 0 8}$ 4892-4896. (https://doi.org/10.1073/ pnas.1018202108)

Jones DP 2006 Redefining oxidative stress. Antioxidants and Redox Signaling 8 1865-1879. (https://doi.org/10.1089/ars.2006.8.1865)

Kim KS \& Gerton GL 2003 Differential release of soluble and matrix components: evidence for intermediate states of secretion during spontaneous acrosomal exocytosis in mouse sperm. Developmental Biology 264 141-152. (https://doi.org/10.1016/j.ydbio.2003.08.006)

Krumschnabel G, Schwarzbaum PJ \& Wieser W 1999 Energetics of trout hepatocytes during A23187-induced disruption of Ca2+ homeostasis. Comparative Biochemistry and Physiology. Part C, Pharmacology, Toxicology and Endocrinology 124 187-195. (https://doi.org/10.1016/ S0742-8413(99)00058-4)
Lange-Consiglio A \& Cremonesi F 2012163 Hyperactivation of stallion sperm in follicular fluid for in vitro fertilization of equine oocytes. Reproduction, Fertility and Development 24 193-194. (https://doi. org/10.1071/RDv24n1Ab163)

Leclerc P, de Lamirande E \& Gagnon C 1996 Cyclic adenosine 3',5'monophosphate-dependent regulation of protein tyrosine phosphorylation in relation to human sperm capacitation and motility. Biology of Reproduction 55 684-692. (https://doi.org/10.1095/ biolreprod55.3.684)

Leemans B, Gadella BM, Sostaric E, Nelis H, Stout TA, Hoogewijs M \& Van Soom A 2014 Oviduct binding and elevated environmental ph induce protein tyrosine phosphorylation in stallion spermatozoa. Biology of Reproduction 91 13. (https://doi.org/10.1095/biolreprod.113.116418)

Leemans B, Gadella BM, Stout TA, Heras S, Smits K, Ferrer-Buitrago M, Claes E, Heindryckx B, De Vos WH, Nelis H et al. 2015a Procaine induces cytokinesis in horse oocytes via a $\mathrm{pH}$ dependent mechanism. Biology of Reproduction 93 23. (https://doi.org/10.1095/biolreprod.114.127423)

Leemans B, Gadella BM, Stout TA, Nelis H, Hoogewijs M \& Van Soom A $2015 b$ An alkaline follicular fluid fraction induces capacitation and limited release of oviduct epithelium-bound stallion sperm. Reproduction 150 193-208. (https://doi.org/10.1530/REP-15-0178)

Leemans B, Gadella BM, Stout TA, De Schauwer C, Nelis H, Hoogewijs M \& Van Soom A 2016a Why doesn't conventional IVF work in the horse? The equine oviduct as a microenvironment for capacitation/fertilization. Reproduction 152 R233-R245. (https://doi.org/10.1530/REP-16-0420)

Leemans B, Gadella BM, Stout TA, Sostaric E, Schauwer CD, Nelis H, Hoogewijs M \& Van Soom A $2016 b$ Combined albumin and bicarbonate induces head-to-head sperm agglutination which physically prevents equine sperm-oviduct binding. Reproduction 151 313-330. (https://doi. org/10.1530/REP-15-0471)

Li LY, Meintjes M, Graff KJ, Paul JB, Denniston RS \& Godke RA 1995 In vitro fertilization and development of in vitro-matured oocytes aspirated from pregnant mares. Biology of Reproduction 1 309-317. (https://doi. org/10.1093/biolreprod/52.monograph_series1.309)

Liguori L, Rambotti MG, Bellezza I \& Minelli A 2004 Electron microscopic cytochemistry of adenylyl cyclase activity in mouse spermatozoa. Journal of Histochemistry and Cytochemistry 52 833-836. (https://doi. org/10.1369/jhc.3B6141.2004)

Lindemann CB \& Lesich KA 2010 Flagellar and ciliary beating: the proven and the possible. Journal of Cell Science 123 519-528. (https://doi. org/10.1242/jcs.051326)

Lishko PV, Botchkina IL, Fedorenko A \& Kirichok Y 2010 Acid extrusion from human spermatozoa is mediated by flagellar voltage-gated proton channel. Cell 140 327-337. (https://doi.org/10.1016/j.cell.2009.12.053)

Lishko PV, Botchkina IL \& Kirichok Y 2011 Progesterone activates the principal Ca2+ channel of human sperm. Nature 471 387-391. (https:// doi.org/10.1038/nature09767)

Litvin TN, Kamenetsky M, Zarifyan A, Buck J \& Levin LR 2003 Kinetic properties of "soluble" adenylyl cyclase. Synergism between calcium and bicarbonate. Journal of Biological Chemistry 278 15922-15926. (https://doi.org/10.1074/jbc.M212475200)

Liu B, Wang P, Wang Z \& Zhang W 2011 The use of anti-VDAC2 antibody for the combined assessment of human sperm acrosome integrity and ionophore A23187-induced acrosome reaction. PLoS One 6 e16985. (https://doi.org/10.1371/journal.pone.0016985)

Loux SC, Crawford KR, Ing NH, Gonzalez-Fernandez L, Macias-Garcia B, Love CC, Varner DD, Velez IC, Choi YH \& Hinrichs K 2013 CatSper and the relationship of hyperactivated motility to intracellular calcium and $\mathrm{pH}$ kinetics in equine sperm. Biology of Reproduction 89 123. (https:// doi.org/10.1095/biolreprod.113.111708)

Loux SC, Macias-Garcia B, Gonzalez-Fernandez L, Canesin HD, Varner DD \& Hinrichs K 2014 Regulation of axonemal motility in demembranated equine sperm. Biology of Reproduction 91 152. (https://doi.org/10.1095/ biolreprod.114.122804)

Maas DH, Storey BT \& Mastroianni L Jr 1977 Hydrogen ion and carbon dioxide content of the oviductal fluid of the rhesus monkey (Macaca mulatta). Fertility and Sterility 28 981-985. (https://doi.org/10.1016/ S0015-0282(16)42801-3)

Macias Garcia B, Gonzalez Fernandez L, Loux SC, Rocha AM, Guimaraes T, Pena FJ, Varner DD \& Hinrichs K 2015 Effect of calcium, bicarbonate and albumin on capacitation-related events in equine sperm. Reproduction 149 87-99. (https://doi.org/10.1530/REP-14-0457) 
Mahony MC \& Gwathmey T 1999 Protein tyrosine phosphorylation during hyperactivated motility of cynomolgus monkey (Macaca fascicularis) spermatozoa. Biology of Reproduction 60 1239-1243. (https://doi. org/10.1095/biolreprod60.5.1239)

Mandal A, Naaby-Hansen S, Wolkowicz MJ, Klotz K, Shetty J, Retief JD, Coonrod SA, Kinter M, Sherman N, Cesar F et al. 1999 FSP95, a testis-specific 95-kilodalton fibrous sheath antigen that undergoes tyrosine phosphorylation in capacitated human spermatozoa. Biology of Reproduction 61 1184-1197. (https://doi.org/10.1095/ biolreprod61.5.1184)

Mann T 1975 Biochemistry of stallion semen. Journal of Reproduction and Fertility Supplement 47-52.

Marin-Briggiler $\mathrm{CI}$, Jha $\mathrm{KN}$, Chertihin O, Buffone MG, Herr JC, Vazquez-Levin MH \& Visconti PE 2005 Evidence of the presence of calcium/calmodulin-dependent protein kinase IV in human sperm and its involvement in motility regulation. Journal of Cell Science $\mathbf{1 1 8}$ 2013-2022. (https://doi.org/10.1242/jcs.02326)

Marquez B \& Suarez SS 2004 Different signaling pathways in bovine sperm regulate capacitation and hyperactivation. Biology of Reproduction 70 1626-1633. (https://doi.org/10.1095/biolreprod.103.026476)

Marquez B \& Suarez SS 2007 Bovine sperm hyperactivation is promoted by alkaline-stimulated Ca2+ influx. Biology of Reproduction 76 660-665. (https://doi.org/10.1095/biolreprod.106.055038)

McPartlin LA, Littell J, Mark E, Nelson JL, Travis AJ \& Bedford-Guaus S] 2008 A defined medium supports changes consistent with capacitation in stallion sperm, as evidenced by increases in protein tyrosine phosphorylation and high rates of acrosomal exocytosis. Theriogenology 69 639-650. (https://doi.org/10.1016/j.theriogenology.2007.11.016)

McPartlin LA, Suarez SS, Czaya CA, Hinrichs K \& Bedford-Guaus SJ 2009 Hyperactivation of stallion sperm is required for successful in vitro fertilization of equine oocytes. Biology of Reproduction 81 199-206. (https://doi.org/10.1095/biolreprod.108.074880)

McPartlin LA, Visconti PE \& Bedford-Guaus SJ 2011 Guanine-nucleotide exchange factors (RAPGEF3/RAPGEF4) induce sperm membrane depolarization and acrosomal exocytosis in capacitated stallion sperm. Biology of Reproduction 85 179-188. (https://doi.org/10.1095/ biolreprod.110.085555)

Meizel S 2004 The sperm, a neuron with a tail: 'neuronal' receptors in mammalian sperm. Biological Reviews of the Cambridge Philosophical Society 79 713-732. (https://doi.org/10.1017/S1464793103006407)

Melendrez CS \& Meizel S 1995 Studies of porcine and human sperm suggesting a role for a sperm glycine receptor/Cl- channel in the zona pellucida-initiated acrosome reaction. Biology of Reproduction 53 676-683. (https://doi.org/10.1095/biolreprod53.3.676)

Meyers SA, Liu IK, Overstreet JW, Vadas S \& Drobnis EZ 1996 Zona pellucida binding and zona-induced acrosome reactions in horse spermatozoa: comparisons between fertile and subfertile stallions. Theriogenology $46 \quad 1277-1288 . \quad$ (https://doi.org/10.1016/S0093 691X(96)00299-3)

Mugnier S, Dell'Aquila ME, Pelaez J, Douet C, Ambruosi B, De Santis T, Lacalandra GM, Lebos C, Sizaret PY, Delaleu B et al. 2009a New insights into the mechanisms of fertilization: comparison of the fertilization steps, composition, and structure of the zona pellucida between horses and pigs. Biology of Reproduction 81 856-870. (https://doi.org/10.1095/ biolreprod.109.077651)

Mugnier S, Kervella M, Douet C, Canepa S, Pascal G, Deleuze S, Duchamp G Monget P \& Goudet G 2009b The secretions of oviduct epithelial cells increase the equine in vitro fertilization rate: are osteopontin, atrial natriuretic peptide A and oviductin involved? Reproductive Biology and Endocrinology 7 129. (https://doi.org/10.1186/1477-7827-7-129)

Mujica A, Neri-Bazan L, Tash JS \& Uribe S 1994 Mechanism for procainemediated hyperactivated motility in guinea pig spermatozoa. Molecula Reproduction and Development 38 285-292. (https://doi.org/10.1002/ mrd.1080380309)

Mukai C \& Okuno M 2004 Glycolysis plays a major role for adenosine triphosphate supplementation in mouse sperm flagellar movement. Biology of Reproduction 71 540-547. (https://doi.org/10.1095/ biolreprod.103.026054)

Naaby-Hansen S, Wolkowicz MJ, Klotz K, Bush LA, Westbrook VA, Shibahara H, Shetty J, Coonrod SA, Reddi PP, Shannon J et al. 2001 Colocalization of the inositol 1,4,5-trisphosphate receptor and calreticulin in the equatorial segment and in membrane bounded vesicles in the cytoplasmic droplet of human spermatozoa. Molecular Human Reproduction 7 923-933. (https://doi.org/10.1093/molehr/7.10.923)

Navarro B, Kirichok Y \& Clapham DE 2007 KSper, a pH-sensitive K+ current that controls sperm membrane potential. PNAS 104 7688-7692. (https://doi.org/10.1073/pnas.0702018104)

Navarro B, Kirichok Y, Chung JJ \& Clapham DE 2008 lon channels that control fertility in mammalian spermatozoa. International Journal of Developmental Biology 52 607-613. (https://doi.org/10.1387/ ijdb.072554bn)

Olds-Clarke P 1989 Sperm from tw32/+ mice: capacitation is normal, but hyperactivation is premature and nonhyperactivated sperm are slow. Developmental Biology 131 475-482. (https://doi.org/10.1016/S00121606(89)80018-1)

Olson SD, Suarez SS \& Fauci LJ 2010 A model of CatSper channel mediated calcium dynamics in mammalian spermatozoa. Bulletin of Mathematical Biology 72 1925-1946. (https://doi.org/10.1007/s11538-010-9516-5)

O'Rand MG \& Fisher SJ 1987 Localization of zona pellucida binding sites on rabbit spermatozoa and induction of the acrosome reaction by solubilized zonae. Developmental Biology 119 551-559. (https://doi. org/10.1016/0012-1606(87)90058-3)

Ortega-Ferrusola C, Anel-Lopez L, Martin-Munoz P, Ortiz-Rodriguez JM, Gil MC, Alvarez M, de Paz P, Ezquerra LJ, Masot AJ, Redondo E et al. 2017 Computational flow cytometry reveals that cryopreservation induces spermptosis but subpopulations of spermatozoa may experience capacitation-like changes. Reproduction 153 293-304. (https://doi. org/10.1530/REP-16-0539)

Ortega Ferrusola C, Gonzalez Fernandez L, Morrell JM, Salazar Sandoval C, Macias Garcia B, Rodriguez-Martinez H, Tapia JA \& Pena FJ 2009 Lipid peroxidation, assessed with BODIPY-C11, increases after cryopreservation of stallion spermatozoa, is stallion-dependent and is related to apoptotic-like changes. Reproduction 138 55-63. (https://doi. org/10.1530/REP-08-0484)

Osheroff JE, Visconti PE, Valenzuela JP, Travis AJ, Alvarez J \& Kopf GS 1999 Regulation of human sperm capacitation by a cholesterol efflux-stimulated signal transduction pathway leading to protein kinase A-mediated up-regulation of protein tyrosine phosphorylation. Molecular Human Reproduction 5 1017-1026. (https://doi.org/10.1093/ molehr/5.11.1017)

Palmer E, Bezard J, Magistrini M \& Duchamp G 1991 In vitro fertilization in the horse. A retrospective study. Journal of Reproduction and Fertility Supplement 44 375-384.

Parrish JJ, Susko-Parrish J, Winer MA \& First NL 1988 Capacitation of bovine sperm by heparin. Biology of Reproduction 38 1171-1180. (https://doi.org/10.1095/biolreprod38.5.1171)

Perry G 20132012 statistics of embryo collection and transfer in domestic farm animals. Embryo Transfer Newsletter 31 1-67.

Plaza Davila M, Martin Munoz P, Tapia JA, Ortega Ferrusola C, Balao da Silva CC \& Pena FJ 2015 Inhibition of mitochondrial Complex I leads to decreased motility and membrane integrity related to increased hydrogen peroxide and reduced ATP production, while the inhibition of glycolysis has less impact on sperm motility. PLoS One 10 e0138777. (https://doi.org/10.1371/journal.pone.0138777)

Pommer AC, Rutllant J \& Meyers SA 2003 Phosphorylation of protein tyrosine residues in fresh and cryopreserved stallion spermatozoa under capacitating conditions. Biology of Reproduction 68 1208-1214. (https://doi.org/10.1095/biolreprod.102.011106)

Qi H, Moran MM, Navarro B, Chong JA, Krapivinsky G, Krapivinsky L, Kirichok Y, Ramsey IS, Quill TA \& Clapham DE 2007 All four CatSper ion channel proteins are required for male fertility and sperm cell hyperactivated motility. PNAS 104 1219-1223. (https://doi.org/10.1073/ pnas.0610286104)

Quill TA, Sugden SA, Rossi KL, Doolittle LK, Hammer RE \& Garbers DL 2003 Hyperactivated sperm motility driven by CatSper2 is required for fertilization. PNAS $\mathbf{1 0 0}$ 14869-14874. (https://doi.org/10.1073/ pnas.2136654100)

Rathi R, Colenbrander B, Bevers MM \& Gadella BM 2001 Evaluation of in vitro capacitation of stallion spermatozoa. Biology of Reproduction $\mathbf{6 5}$ 462-470. (https://doi.org/10.1095/biolreprod65.2.462)

Rathi R, Colenbrander B, Stout TA, Bevers MM \& Gadella BM 2003 Progesterone induces acrosome reaction in stallion spermatozoa via a protein tyrosine kinase dependent pathway. Molecular Reproduction and Development 64 120-128. (https://doi.org/10.1002/mrd.10216) 
Ren D, Navarro B, Perez G, Jackson AC, Hsu S, Shi Q, Tilly JL \& Clapham DE 2001 A sperm ion channel required for sperm motility and male fertility. Nature 413 603-609. (https://doi.org/10.1038/35098027)

Roasa LM, Choi YH, Love CC, Romo S, Varner DD \& Hinrichs K 2007 Ejaculate and type of freezing extender affect rates of fertilization of horse oocytes in vitro. Theriogenology 68 560-566. (https://doi.org/10.1016/j. theriogenology.2007.04.057)

Roggero CM, De Blas GA, Dai H, Tomes CN, Rizo J \& Mayorga LS 2007 Complexin/synaptotagmin interplay controls acrosomal exocytosis. Journal of Biological Chemistry 282 26335-26343. (https://doi. org/10.1074/jbc.M700854200)

Saaranen MJ, Calvo L, Dennison L, Banks S, Bustillo M, Dorfmann AD, Goldstein M, Thorsell L, Schulman JD \& Sherins RJ 1993 Acrosome reaction inducing activity in follicular fluid correlates with progesterone concentration but not with oocyte maturity or fertilizability. Human Reproduction 8 1448-1454. (https://doi.org/10.1093/oxfordjournals. humrep.a138277)

Schlingmann K, Michaut MA, McElwee JL, Wolff CA, Travis AJ \& Turner RM 2007 Calmodulin and CaMKII in the sperm principal piece: evidence for a motility-related calcium/calmodulin pathway. Journal of Andrology $\mathbf{2 8}$ 706-716. (https://doi.org/10.2164/jandrol.106.001669)

Shingyoji C, Murakami A \& Takahashi K 1977 Local reactivation of Tritonextracted flagella by iontophoretic application of ATP. Nature $\mathbf{2 6 5}$ 269-270. (https://doi.org/10.1038/265269a0)

Si Y 1999 Hyperactivation of hamster sperm motility by temperaturedependent tyrosine phosphorylation of an 80-kDa protein. Biology of Reproduction 61 247-252. (https://doi.org/10.1095/biolreprod61.1.247)

Si Y \& Okuno M 1999 Role of tyrosine phosphorylation of flagellar proteins in hamster sperm hyperactivation. Biology of Reproduction 61 240-246. (https://doi.org/10.1095/biolreprod61.1.240)

Si Y \& Olds-Clarke P 2000 Evidence for the involvement of calmodulin in mouse sperm capacitation. Biology of Reproduction 62 1231-1239. (https://doi.org/10.1095/biolreprod62.5.1231)

Signorelli J, Diaz ES \& Morales P 2012 Kinases, phosphatases and proteases during sperm capacitation. Cell and Tissue Research 349 765-782. (https://doi.org/10.1007/s00441-012-1370-3)

Simons K \& Toomre D 2000 Lipid rafts and signal transduction. Nature Reviews. Molecular Cell Biology 1 31-39. (https://doi. org/10.1038/35036052)

Smith GD, Wolf DP, Trautman KC, da Cruz e Silva EF, Greengard P \& Vijayaraghavan S 1996 Primate sperm contain protein phosphatase 1, a biochemical mediator of motility. Biology of Reproduction 54 719-727. (https://doi.org/10.1095/biolreprod54.3.719)

Stauss CR, Votta TJ \& Suarez SS 1995 Sperm motility hyperactivation facilitates penetration of the hamster zona pellucida. Biology of Reproduction 53 1280-1285. (https://doi.org/10.1095/ biolreprod53.6.1280)

Steptoe PC \& Edwards RG 1978 Birth after the reimplantation of a human embryo. Lancet 2 366. (https://doi.org/10.1016/S0140-6736(78)92957-4)

Storey BT 2008 Mammalian sperm metabolism: oxygen and sugar, friend and foe. International Journal of Developmental Biology 52 427-437. (https://doi.org/10.1387/ijdb.072522bs)

Suarez SS 2002 Formation of a reservoir of sperm in the oviduct. Reproduction in Domestic Animals 37 140-143. (https://doi. org/10.1046/j.1439-0531.2002.00346.x)

Suarez SS 2008 Control of hyperactivation in sperm. Human Reproduction Update 14 647-657. (https://doi.org/10.1093/humupd/dmn029)

Suarez SS \& Dai X 1992 Hyperactivation enhances mouse sperm capacity for penetrating viscoelastic media. Biology of Reproduction 46 686-691. (https://doi.org/10.1095/biolreprod46.4.686)

Suarez SS \& Pacey AA 2006 Sperm transport in the female reproductive tract. Human Reproduction Update 12 23-37. (https://doi.org/10.1093/ humupd/dmi047)

Suarez SS, Vincenti L \& Ceglia MW 1987 Hyperactivated motility induced in mouse sperm by calcium ionophore A23187 is reversible. Journal of Experimental Zoology 244 331-336. (https://doi.org/10.1002/ jez.1402440218)

Suarez SS, Varosi SM \& Dai X 1993 Intracellular calcium increases with hyperactivation in intact, moving hamster sperm and oscillates with the flagellar beat cycle. PNAS 90 4660-4664. (https://doi.org/10.1073/ pnas.90.10.4660)
Takakura K, Beckman JS, MacMillan-Crow LA \& Crow JP 1999 Rapid and irreversible inactivation of protein tyrosine phosphatases PTP1B, CD45, and LAR by peroxynitrite. Archives of Biochemistry and Biophysics 369 197-207. (https://doi.org/10.1006/abbi.1999.1374)

Tapia JC, Espinoza F \& Aguayo LG 1997 Differential intracellular regulation of cortical GABA(A) and spinal glycine receptors in cultured neurons. Brain Research 769 203-210. (https://doi.org/10.1016/S00068993(97)00672-0)

Tash JS 1989 Protein phosphorylation: the second messenger signal transducer of flagellar motility. Cell Motility and the Cytoskeleton $\mathbf{1 4}$ 332-339. (https://doi.org/10.1002/cm.970140303)

Tash JS \& Means AR 1983 Cyclic adenosine 3',5' monophosphate, calcium and protein phosphorylation in flagellar motility. Biology of Reproduction 28 75-104. (https://doi.org/10.1095/biolreprod28.1.75)

Tash JS \& Bracho GE 1994 Regulation of sperm motility: emerging evidence for a major role for protein phosphatases. Journal of Andrology 15 505-509.

Tash JS, Krinks M, Patel J, Means RL, Klee CB \& Means AR 1988 Identification, characterization, and functional correlation of calmodulin-dependent protein phosphatase in sperm. Journal of Cell Biology 106 1625-1633. (https://doi.org/10.1083/jcb.106.5.1625)

Tateno H, Krapf D, Hino T, Sanchez-Cardenas C, Darszon A, Yanagimachi R \& Visconti PE 2013 Ca2+ ionophore A23187 can make mouse spermatozoa capable of fertilizing in vitro without activation of cAMP-dependent phosphorylation pathways. PNAS 110 18543-18548. (https://doi.org/10.1073/pnas.1317113110)

Tremoleda JL, Gadella BM, Stout T, Colenbrander B \& Bevers MM 2003 Evaluation of Sperm-Oocyte Interaction During in Vitro Fertilization in the Horse. Utrecht University, pp. 67-91.

Trevino CL, Santi CM, Beltran C, Hernandez-Cruz A, Darszon A \& Lomeli H 1998 Localisation of inositol trisphosphate and ryanodine receptors during mouse spermatogenesis: possible functional implications. Zygote 6 159-172. (https://doi.org/10.1017/S0967199498000094)

Tsai PS, Garcia-Gil N, van Haeften T \& Gadella BM 2010 How pig sperm prepares to fertilize: stable acrosome docking to the plasma membrane. PLoS One 5 e11204. (https://doi.org/10.1371/journal. pone.0011204)

Tsai PS, Brewis IA, van Maaren J \& Gadella BM 2012 Involvement of complexin 2 in docking, locking and unlocking of different SNARE complexes during sperm capacitation and induced acrosomal exocytosis. PLoS One 7 e32603. (https://doi.org/10.1371/journal.pone.0032603)

Turner RM 2006 Moving to the beat: a review of mammalian sperm motility regulation. Reproduction, Fertility, and Development 18 25-38. (https://doi.org/10.1071/RD05120)

van Gestel RA, Brewis IA, Ashton PR, Helms JB, Brouwers JF \& Gadella BM 2005a Capacitation-dependent concentration of lipid rafts in the apical ridge head area of porcine sperm cells. Molecular Human Reproduction 11 583-590. (https://doi.org/10.1093/molehr/gah200)

van Gestel RA, Helms JB, Brouwers JF \& Gadella BM 2005b Effects of methyl-beta-cyclodextrin-mediated cholesterol depletion in porcine sperm compared to somatic cells. Molecular Reproduction and Development 72 386-395. (https://doi.org/10.1002/mrd.20351)

van Gestel RA, Brewis IA, Ashton PR, Brouwers JF \& Gadella BM 2007 Multiple proteins present in purified porcine sperm apical plasma membranes interact with the zona pellucida of the oocyte. Molecular Human Reproduction 13 445-454. (https://doi.org/10.1093/molehr/ gam030)

Vigil P 1989 Gamete membrane fusion in hamster spermatozoa with reacted equatorial segment. Gamete Research 23 203-213. (https://doi. org/10.1002/mrd.1120230207)

Vijayaraghavan S, Stephens DT, Trautman K, Smith GD, Khatra B, da Cruz e Silva EF \& Greengard P 1996 Sperm motility development in the epididymis is associated with decreased glycogen synthase kinase- 3 and protein phosphatase 1 activity. Biology of Reproduction 54 709-718. (https://doi.org/10.1095/biolreprod54.3.709)

Visconti PE, Bailey JL, Moore GD, Pan D, Olds-Clarke P \& Kopf GS 1995a Capacitation of mouse spermatozoa. I. Correlation between the capacitation state and protein tyrosine phosphorylation. Development 121 1129-1137.

Visconti PE, Moore GD, Bailey JL, Leclerc P, Connors SA, Pan D, OldsClarke P \& Kopf GS 1995 b Capacitation of mouse spermatozoa. II. 
Protein tyrosine phosphorylation and capacitation are regulated by a cAMP-dependent pathway. Development 121 1139-1150.

Visconti PE, Johnson LR, Oyaski M, Fornes M, Moss SB, Gerton GL \& Kopf GS 1997 Regulation, localization, and anchoring of protein kinase A subunits during mouse sperm capacitation. Developmental Biology 192 351-363. (https://doi.org/10.1006/dbio.1997.8768)

Visconti PE, Galantino-Homer H, Ning X, Moore GD, Valenzuela JP, Jorgez CJ, Alvarez JG \& Kopf GS 1999a Cholesterol efflux-mediated signal transduction in mammalian sperm. Journal of Biological Chemistry 274 3235-3242. (https://doi.org/10.1074/jbc.274.5.3235)

Visconti PE, Stewart-Savage J, Blasco A, Battaglia L, Miranda P, Kopf GS \& Tezon JG 1999b Roles of bicarbonate, cAMP, and protein tyrosine phosphorylation on capacitation and the spontaneous acrosome reaction of hamster sperm. Biology of Reproduction 61 76-84. (https:// doi.org/10.1095/biolreprod61.1.76)

Vjugina U \& Evans JP 2008 New insights into the molecular basis of mammalian sperm-egg membrane interactions. Frontiers in Bioscience 13 462-476. (https://doi.org/10.2741/2693)

Wargo MJ \& Smith EF 2003 Asymmetry of the central apparatus defines the location of active microtubule sliding in Chlamydomonas flagella. PNAS 100 137-142. (https://doi.org/10.1073/pnas.0135800100)

Watson PF 2000 The causes of reduced fertility with cryopreserved semen. Animal Reproduction Science 60-61 481-492. (https://doi.org/10.1016/ S0378-4320(00)00099-3)

Weaver CD, Partridge JG, Yao TL, Moates JM, Magnuson MA \& Verdoorn TA 1998 Activation of glycine and glutamate receptors increases intracellular calcium in cells derived from the endocrine pancreas. Molecular Pharmacology 54 639-646.
White DR \& Aitken RJ 1989 Relationship between calcium, cyclic AMP, ATP, and intracellular $\mathrm{pH}$ and the capacity of hamster spermatozoa to express hyperactivated motility. Gamete Research 22 163-177. (https:// doi.org/10.1002/mrd.1120220205)

Wiesner B, Weiner J, Middendorff R, Hagen V, Kaupp UB \& Weyand I 1998 Cyclic nucleotide-gated channels on the flagellum control Ca2+ entry into sperm. Journal of Cell Biology 142 473-484. (https://doi. org/10.1083/jcb.142.2.473)

Yanagimachi R 1994 Mammalian fertilization. In The Physiology of Reproduction, pp. 189-317. Eds JD Neill \& E Knobil. New York: Raven Press.

Zeng Y, Oberdorf JA \& Florman HM $1996 \mathrm{pH}$ regulation in mouse sperm: identification of $\mathrm{Na}(+)-, \quad \mathrm{Cl}(-)-$, and $\mathrm{HCO} 3(-)$-dependent and arylaminobenzoate-dependent regulatory mechanisms and characterization of their roles in sperm capacitation. Developmental Biology 173 510-520. (https://doi.org/10.1006/dbio.1996.0044)

Zhang JJ, Muzs LZ \& Boyle MS 1990 In vitro fertilization of horse follicular oocytes matured in vitro. Molecular Reproduction and Development 26 361-365. (https://doi.org/10.1002/mrd.1080260411)

Received 15 October 2018

First decision 10 December 2018

Revised manuscript received 25 December 2018

Accepted 4 February 2019 